\title{
Characterizations of Larval Gut Bacteria of Anopheles Subpictus Grassi and Their Role in Mosquito Development in Hooghly, West Bengal, India.
}

Madhurima Seal

The University of Burdwan

Soumendranath Chatterjee ( $\sim$ soumen.mcrobiology@gmail.com )

The University of Burdwan

\section{Research Article}

Keywords: Malaria, Mosquito, Bacteria, Development, Vector

Posted Date: July 16th, 2021

DOI: https://doi.org/10.21203/rs.3.rs-707008/v1

License: (c) (1) This work is licensed under a Creative Commons Attribution 4.0 International License. Read Full License 


\section{Abstract}

Malaria is a serious vector borne disease transmitted by different species of Anopheles mosquitoes. The present study was aimed to isolate \& characterize the bacterial flora from the gut of An. subpictus larvae prevalent in Hooghly and explore their roles in host survival and development. Mosquito larvae and adults were collected from field and were maintained in laboratory. Bacterial load in the larval midgut was determined, predominant strains were isolated and characterized by polyphasic approach. Role of these bacteria in larval survival \& development were assayed. Bacterial load in the gut of larvae was found to vary in field collected and lab reared mosquitoes in different seasons. Morphological, bio-chemical and molecular analysis explored four common bacterial isolates namely Bacillus subtilis, Bacillus pumilus, Bacillus cereus \& Proteus vulgaris in the larval gut throughout the year. Larval survival rate was greatly reduced (0.06) \& time of pupation was prolonged (17.8 \pm 0.57$)$ in absence of their gut bacteria. Total tissue protein (7.78 \pm 0.56$)$, lipid $(2.25 \pm 0.19)$ \& carbohydrate $(16.5 \pm 0.79)$ contents of larvae and body weight \& wing length of adult male $(0.17 \pm 0.02 \& 1.74 \pm 0.43) \&$ female $(0.19 \pm 0.02 \& 1.99 \pm 0.46)$ mosquitoes were also found to be greatly reduced in the absence of gut bacteria. Developmental characteristics were restored with the introduction of culture suspension of all four resident gut bacterial isolates. Present study indicates that the mosquitoes solely depend on their gut bacteria for their survival \& development. So, manipulation or control of this gut bacterial communities might inhibit survival \& development of vector mosquitoes.

\section{Introduction}

Mosquitoes of different genera like Anopheles, Culex \& Aedes serve as vectors of numerous disease-causing pathogens throughout different parts of the world [1, 2]. Among them different species of Anopheles mosquitoes serve as vectors of malarial disease, which is one of the major cause of mortality and morbidity throughout different regions of the world [3, 4]. Anopheles subpictus Grassi 1899 (Sub species A, freshwater breeder) has been reported to act as a potent malarial vector in different parts of the world [5-7] including rural areas of Hooghly, West Bengal, India [8]. Transmission of pathogens by mosquito vectors depends on numerous factors including the climatic condition of the region [9], host-vector contact [10], physiology of the host [11] etc. All insects including mosquitoes harbor a large number of microbial communities in their gut environment, some of them have symbiotic associations with their hosts $[12,13]$. These microbial communities play different roles in several life history processes of their hosts starting from their survival, development $[13,14]$ to their reproduction [15]. They are also involved in host nutrition by secreting different enzymes which helps to degrade complex molecules into digestible simpler form [16]. They also produce essential nutrients like vitamins or amino acids for their host $[17,18]$. In the blood sucking insects gut bacteria play important role in blood digestion by their host [19]. These microbial communities are also a part of host natural immune system [20]. Even they can modulate the vectorial capacity of their hosts [21]. Previously a large number of bacterial communities have been reported by several researchers from gut of both larval and adult forms of anopheline mosquitoes [22-28]. Some earlier studies have also shown that removal of gut bacteria from mosquito body had several detrimental effects on their host organisms, including their late development, higher mortality and several adult morphological abnormalities [12-14, 29]. But there are very scanty literatures available about the gut bacterial species and their impact on An. subpictus mosquitoes prevalent in rural fresh water bodies of Hooghly district, West Bengal.

So, the present study is aimed to characterize the larval gut bacteria of An. subpictus mosquitoes of rural areas of Hooghly, West Bengal by polyphasic approach to confirm their identity and their subsequent role in larval survival \& development. Proper identification of beneficial gut bacteria of An. subpictus and their subsequent control or any genetic manipulation might generate an avenue of vector management programme in the study areas. 


\section{Materials And Methods}

Mosquito collection and identification: Larvae of An. subpictus were collected from water bodies of some rural areas of Hooghly district by using standard dipper of $250 \mathrm{~mL}$ capacity following standard protocols [30, 31]. Adult mosquitoes were collected within test tubes from cattle sheds and human habitations by hand collection method. All the collections were done once in summer, monsoon, post-monsoon \& winter from february'2017-march'2018 during early morning or in the afternoon. After collection, the larvae and adult mosquitoes were brought to the Parasitology \& Microbiology Research Laboratory, Department of Zoology, The University of Burdwan. Identification of larval and adult forms of mosquitoes were done under microscope following standard keys [32, 33]. Adult An. subpictus mosquitoes were maintained in a mosquito rearing cage $(30 \mathrm{~cm} \times 30 \mathrm{~cm} \times 30 \mathrm{~cm})$ in optimum laboratory condition for egg laying and larval hatching. Some specimens were also sent to Zoological Survey of India, Kolkata for the reconfirmation of the species identification.

Isolation of bacteria: Both field collected and laboratory reared $3^{\text {rd }}$ instar larvae (5-10 in number) of An. subpictus were surface sterilized by placing them in $70 \%$ alcohol for 3-5 mins. Then they were washed with double distilled water and mid-gut of the larvae were dissected carefully in aseptic condition under a binocular (2X magnification). Mid-gut content for laboratory reared and field caught larvae were mixed separately with $1 \mathrm{~mL}$ sterile distilled water and from this mixture $100 \mu \mathrm{L}$ was mixed with sterilized moderately cooled nutrient agar media and poured on five sterile petri plates. The plates were incubated at $37 \pm 2^{0} \mathrm{C}$ temperature in a B.O.D incubator for $24-48 \mathrm{~h}$. On the next day, total number of colonies that were formed over the nutrient agar plates were counted and bacterial load in the mid-gut of larvae were determined as colony forming unit (cfu/mL). Colonies that were formed on the nutrient agar plates were characterized by recording different colony characters (size, shape, colour, opacity, elevation \& consistency). Pure cultures of the bacterial isolates were maintained on nutrient agar slants in a refrigerator at $4 \pm 1^{\circ} \mathrm{C}$ temperature for further analysis.

\section{Characterizations of larval gut bacterial isolates}

\section{Phenotypic characterizations}

Phenotypic properties of bacterial isolates such as Gram staining properties, presence of endospores were evaluated by staining with Gram's stain and 5\% Malachite green solutions respectively. Scanning electron microscopic analysis was performed to observe the surface morphologies of vegetative cells of the bacterial isolates [13].

\section{Bio-chemical characterizations}

Several bio-chemical properties of the bacterial isolates such as catalase; methyl red; indole; voges proskauer test; citrate test; oxidase test; urease test; growth on Triple Sugar Iron (TSI) agar; starch, protein \& lipid hydrolysis test, nitrate reduction test and fermentation ability of twenty different carbohydrate sources such as dextrose (De), fructose $(\mathrm{Fc})$, galactose $(\mathrm{Ga})$, sucrose $(\mathrm{Su})$, lactose $(\mathrm{La})$, mannitol $(\mathrm{Mn})$, cellobiose $(\mathrm{Ce})$, dulcitol (Du), trehalose (Te), raffinose (Rf), sorbitol (Sb), xylose (Xy), melibiose (Mb), rhamnose (Rh), arabinose (Ar), mannose (Mo), lactose (La), adonitol (Ad), salicin (Sa) and inulin (In) were performed following standard methodologies [34-36].

\section{Physiological characterizations}

Physiological properties of the gut bacterial isolates like sodium chloride $(\mathrm{NaCl})$ tolerance, growth at different $\mathrm{pH}$ scale and different temperature of the culture media were recorded following standard methodologies [34-36].

\section{Molecular characterizations}


Genomic DNA were isolated from the overnight grown liquid bacterial cultures following standard method [37] and $16 \mathrm{~S}$ rDNA sequences were amplified by polymerase chain reaction by using $27 \mathrm{~F}$ forward and $1492 \mathrm{R}$ primer. The PCR purified products were sequenced bi-directionally using universal primers. The obtained 16S rRNA gene sequences of the bacterial isolates were submitted to NCBI GenBank. Nucleotide percentages of 16S rRNA gene sequences of the bacterial isolates were calculated using Aqua software. Phylogenetic analysis was done by neighbour-joining method using MEGA X software [38].

\section{Antibiotic sensitivity of bacterial isolates}

Susceptibility of the bacterial isolates to twenty different commercially available standard antibiotics namely bacitracin (10 $\mu \mathrm{g} /$ disc), nalidixic acid (30 $\mu \mathrm{g} /$ disc), kanamycin (30 $\mu \mathrm{g} / \mathrm{disc})$, ampicillin (10 $\mu \mathrm{g} / \mathrm{disc})$, amoxicillin (10 $\mu \mathrm{g} / \mathrm{disc})$, penicillin (10 $\mathrm{g}$ /disc), levofloxacin (5 $\mathrm{g} / \mathrm{disc})$, chloramphenicol (30 $\mu \mathrm{g} / \mathrm{disc})$, gentamicin (50 $\mu \mathrm{g} / \mathrm{disc})$, neomycin (30 $\mu \mathrm{g} / \mathrm{disc})$, tetracycline $(30 \mu \mathrm{g} / \mathrm{disc})$, ofloxacin $(5 \mu \mathrm{g} / \mathrm{disc})$, norfloxacin $(10 \mu \mathrm{g} / \mathrm{disc})$, rifampicin (5 $\mu \mathrm{g} /$ disc), ciprofloxacin (5 $\mu \mathrm{g} / \mathrm{disc})$, vancomycin (30 $\mu \mathrm{g} / \mathrm{disc})$, azithromycin (30 $\mu \mathrm{g} / \mathrm{disc})$, erythromycin (15 $\mu \mathrm{g} / \mathrm{disc})$, doxycycline (30 $\mathrm{\mu g} / \mathrm{disc})$ and streptomycin $(10 \mu \mathrm{g} / \mathrm{disc})$ were tested on Muller-Hinton agar plates by disc diffusion method [39]. Minimum inhibitory concentration of two broad spectrum antibiotics viz., doxycycline and levofloxacin against the bacterial isolates was determined using MIC strip (Himedia, India).

\section{Role of larval mid-gut bacteria in survival and development of host}

A batch of three hundred $1^{\text {st }}$ instar larvae of An. subpictus were collected from the fresh water bodies and they were kept in a plastic tray $(30 \mathrm{~cm} \times 30 \mathrm{~cm})$ containing $1500 \mathrm{~mL}$ of natural habitat water. Out of these total collected specimens, a group of thirty larvae were maintained in a separate tray containing $100 \mathrm{~mL}$ natural habitat water. This group of larvae were provided with UV sterilized larval food and without any treatment which served as conventionally reared control group. Rest of the larvae were fed with UV sterilized larval food and a mixture of doxycycline and levofloxacin (1:1 ratio) at their minimum inhibitory concentration for 1day to clear the gut bacterial communities. Another group comprised of thirty $1^{\text {st }}$ instar larvae were separated in a plastic tray containing sterile distilled water with UV sterilized larval food. This group served as axenic group. Rest of the antibiotic treated axenic larvae were separated in five trays (30 larvae in each) containing $95 \mathrm{~mL}$ sterile distilled water with UV sterilized larval food. Axenic larvae in the $1^{\text {st }}$ to $4^{\text {th }}$ trays were provided with $5 \mathrm{~mL}$ suspensions of previously isolated individual gut bacteria for their recolonization within larval gut and in the $5^{\text {th }}$ tray axenic larvae were provided with $5 \mathrm{~mL}$ suspension containing a mixture of all gut bacterial isolates. All the larvae were maintained in aseptic condition at $37 \pm 2{ }^{\circ} \mathrm{C}$ temperature, $75 \pm 5 \%$ relative humidity and 12:12h (light: dark) photo period. Five replicates were done for each of the treatment and control groups. Time of pupa formation for each group of larvae were noted down. After pupal emergence, pupae from each batch were kept in separate mosquito rearing cages $(30 \mathrm{~cm} \times 30 \mathrm{~cm} \times 30 \mathrm{~cm})$ and were maintained at $37 \pm 2^{\circ} \mathrm{C}$ temperature, $75 \pm 5 \%$ relative humidity and $12: 12 \mathrm{~h}$ (light: dark) photo period. Number of adult mosquitoes emerged from each group was noted down. Adult males and females emerged from each group were kept separately in test tubes with chloroform applied cotton plugging for 6-7 days. Dry weight of male and female mosquitoes from each group was measured. Wings of male \& female mosquitoes were dissected out, mounted on glass slide with DPX solution. Then images of wings were captured by stereo zoom microscope (Olympus) and the length and breadth of each of the wing were measured with M Shot software.

\section{Bio-chemical profile of larvae in presence and absence of gut bacteria}

Total tissue carbohydrate, protein \& lipid content of $4^{\text {th }}$ instar larvae in each of the treated \& control groups were evaluated. For that purpose, thirty synchronized $4^{\text {th }}$ instar larvae were selected from each group. Total tissue

Page 4/29 
carbohydrate and lipid were extracted [40]. Carbohydrate estimation was done by anthrone reagent [41]. Lipid quantification was done by vanillin-reagent method [42]. Total tissue protein was extracted [43] and estimated using foline-ciocalteau reagent [44].

\section{Statistical analyses}

One way ANOVA was done to compute any significant differences in pupation time, rate of survival up to adulthood, body weight \& wing length of adult male \& female An. subpictus mosquitoes and bio-chemical contents of $4^{\text {th }}$ instar larvae among different treatment groups. Dunnett's multiple comparison tests were performed to evaluate significant difference of each of the treatment group from control group. All the analyses were performed in GraphPad prism 9.0.0.

\section{Results}

Bacterial load in the form of colony forming unit $(\mathrm{cfu} / \mathrm{mL})$ in the mid-gut of both field collected and laboratory reared $3^{\text {rd }}$ instar larvae of An. subpictus was evaluated and is given in Table 1. Bacterial load in all the four seasons was found to be higher in the mid-gut of field collected larvae than laboratory reared one and among four seasons, postmonsoon larvae harboured higher bacterial populations in their mid-gut, whereas during winter season gut bacterial populations of both field collected and laboratory reared larvae were found to be lowest. Among seventeen bacterial isolates recorded by colony morphologies, four isolates (HALG2, HALG4, HALG6 \& HALG7) were found to be common in all the four seasons in both field collected and laboratory reared larvae. So, these four bacterial isolates were assumed to be as the resident bacterial flora of larval mid gut and further characterizations were done for these four bacterial isolates. Colony characteristics of these isolates have been depicted in Table 2. Gram staining and endospore staining revealed that three isolates (HALG2, HALG4 \& HALG6) were rod shaped gram-positive bacteria and were able to produce endospores, whereas HALG7 was gram negative bacterial isolate and was also negative for endospore production (Table 3). Scanning electron microscopic analysis showed that the organisms of four bacterial isolates were rod shaped with single or in short chain arrangement (Fig. 1a-d).

Bio-chemical characteristics and carbohydrate fermentation abilities of these bacterial isolates have been tabulated in Table 4 \& Table 5 respectively. All four bacterial isolates showed positive results for catalase test. None of the isolates were able to produce indole except HALG7. Among four bacterial isolates, two isolates (HALG6 \& HALG7) showed positive reaction for methyl red test whereas rest two isolates (HALG2 \& HALG4) showed negative reaction for methyl red test. All the four isolates showed negative results for VP test. All the four bacterial isolates were negative for citrate utilization test. Among four bacterial isolates, three isolates (HALG2, HALG6 \& HALG7) were able to reduce nitrate. Two of the isolates (HALG4 \& HALG6) were able to produce oxidase enzymes, whereas rest of the two isolates (HALG2 \& HALG7) were negative for oxidase production. Except HALG7, none of the isolates were able to produce urease enzyme. All the four isolates were able to degrade starch, lipid, protein (gelatin) sources of the medium. Motility test showed that all the four bacterial isolates were motile in nature. Growth of the bacterial isolates in TSI agar medium showed that isolate HALG2 \& HALG4 were able to utilize both glucose and sucrose or lactose, in addition to that, during fermentation HALG4 produced gas also, whereas, HALG6 \& HALG7 were able to utilize glucose only. Among the four bacterial isolates, only HALG7 was positive for hydrogen sulphide $\left(\mathrm{H}_{2} \mathrm{~S}\right)$ production. Carbohydrate fermentation tests revealed that all the four isolates were able to ferment dextrose, trehalose \& fructose whereas all of them were unable to ferment lactose, galactose, melibiose, dulcitol, adonitol, rhamnose \& salicin. Among four isolates, only one isolate (HALG2) could able to utilize inositol, arabinose, mannitol, sorbitol, raffinose, mannose \& inulin. Sucrose was fermented by all of the isolates except HALG6. Two of the isolates (HALG2 \& HALG4) were able to ferment cellobiose, whereas, another two isolates HALG6 \& HALG7 could not able to ferment this carbohydrate source. Xylose was utilized 
as fermentable carbon sources by only one isolate (HALG7), but, rest of the three isolates (HALG2, HALG4 \& HALG6) were unable to ferment xylose.

All the four bacterial isolates showed $\mathrm{NaCl}$ tolerance up to $4 \%$ of the growth medium. $\mathrm{pH}$ tolerance test revealed that all the isolates were able to grow from $\mathrm{pH} 5-\mathrm{pH} 9$ of the media although optimum $\mathrm{pH}$ for the bacterial growth ranged between $\mathrm{pH}$ 7- $\mathrm{pH} 8$ (Fig. 2). Growth of the bacterial isolates at different temperatures of the environment showed that although they could grow from $15^{\circ} \mathrm{C}-45^{\circ} \mathrm{C}$ temperature of the medium, but optimum temperature for their growth ranged between $30^{\circ} \mathrm{C}-35^{\circ} \mathrm{C}$ (Fig. 3).

Analysis of nucleotides of 16S rRNA gene sequences of the bacterial isolates revealed that AT \& GC content of 16S rRNA gene sequences of HALG2 was $44.15 \%$ \& $55.84 \%$. The figures were $44.32 \%$ \& $55.68 \%$ for HALG $4,46 \%$ \& $54 \%$ for HAGL6 and $46 \%$ and $54 \%$ for HAGL7 respectively (Fig. 4).

Phylogenetic tree of the bacterial isolates were constructed by neighbor-joining method which showed that HALG2 (MN894011) had direct branching with Bacillus subtilis (MK367787) with 64\% bootstrap value (Fig. 5), HALG4 (MZ363627) branched directly with Bacillus pumilus (KY608827) with 82\% bootstrap value (Fig. 6), HALG6 (MZ363632) had direct branching with Bacillus cereus (JX645714) with 40\% bootstrap value (Fig. 7) and HALG7 (MZ363637) branched directly with Proteus vulgaris (MG596968) with 60\% bootstrap value (Fig. 8). So, after phenotypic, bio-chemical and molecular analysis it was confirmed that the four resident gut bacterial isolates (HALG2, HALG4, HALG6 \& HALG7) were Bacillus subtilis, Bacillus pumilus, Bacillus cereus \& Proteus vulgaris respectively.

Sensitivity of these four resident larval gut bacterial isolates to different commercially available standard antibiotics with their zone diameter inhibition values have been depicted in Table 6. Formation of clear zone surrounding the antibiotic disc on the culture plates indicated their sensitivity to particular antibiotics, whereas absence of any clear zone surrounding the antibiotic disc indicated their resistant property against that particular antibiotic. Minimum inhibitory concentration of two broad spectrum antibiotics (levofloxacin \& doxycycline) against all the four isolates have been given in Table 7.

Time required for pupa formation from $1^{\text {st }}$ instar larvae varied significantly among different treatment groups (ANOVA: $F(6,28)=51.02, p<0.0001)$. Longest time for pupa formation was taken by antibiotic treated axenic group of larvae (average 17.8 days), whereas the conventionally reared larvae (control group) were converted into pupae on an average 7.8 days. One way ANOVA followed by Dunnett's multiple comparison test showed that there was significant difference in time of pupa formation between conventionally reared control group and antibiotic treated axenic group of larvae ( $p<0.0001)$, conventionally reared control group and Bacillus subtilis HALG2 treated larval group ( $<<0.0001)$, conventionally reared control group and Bacillus pumilus HALG4 treated larval group $(p=0.0019)$. Whereas, there were no significant differences in time of pupa formation between conventionally reared control group and Bacillus cereus HALG6, Proteus vulgaris HALG7 and all four isolates treated groups ( $p>0.05$ ) (Fig. 9). Survival of antibiotic treated axenic group of $1^{\text {st }}$ instar larvae and $1^{\text {st }}$ instar axenic larvae that were individually cured with gut bacterial isolates showed significant variation in rate of survival when compared with survival rate of conventionally reared control larvae $(p<0.0001)$. But, the survival rate of $1^{\text {st }}$ instar larvae up to adulthood did not show any significant differences among axenic larvae that were treated with a mixture of all four gut bacterial isolates and conventionally reared control groups ( $p>0.05)$ (Fig. 10).

Body weight of adult male and female An. subpictus mosquitoes that had been developed from conventionally reared control larval groups were found to range between $0.25 \mathrm{mg}-0.39 \mathrm{mg}$ and $0.26 \mathrm{mg}-0.45 \mathrm{mg}$ respectively. Body weight of adult male An. subpictus was significantly reduced in all treatment groups than conventionally reared control group 
$(p<0.001)$, Similarly, significant difference of body weight of adult female An. subpictus (developed from axenic larvae and axenic larvae that were subsequently colonized by individual gut bacterial isolates) was observed when compared with adult females developed from control larvae (conventionally reared group), only the body weight of adult female developed from mixture of all four gut bacteria treated axenic $1^{\text {st }}$ instar larval group did not show any significant difference with body weight of adult female An. subpictus developed from conventionally reared group $(p=0.2452)$ (Fig. 11A \& 11B). Wing length of adult male and female An. subpictus mosquitoes developed from conventionally reared control larval groups ranged between $2.91 \mathrm{~mm}-3.99 \mathrm{~mm}$ and $3.08 \mathrm{~mm}-3.99 \mathrm{~mm}$ respectively. One way ANOVA showed significant variations in wing length of both male $(F(6,135)=54.53, p<0.0001)$ and female $(F(6,152)=47.98$, $\mathrm{p}<0.0001)$ of different groups of mosquitoes. Dunnett's multiple comparison test revealed that mean wing length of adult male and female $A n$. subpictus were reduced significantly in all treatment groups than conventionally reared one $(p<0.0001)$ (Fig. 11C \& 11D). Correlation between body weight \& wing length of adult mosquitoes showed that wing length of both male and female An. subpictus mosquitoes had strong positive correlation with their body weight (Fig. $12 \mathrm{~A} \& 12 \mathrm{~B})$.

Total tissue carbohydrate, protein and lipid contents have been given in Table 8. Average values of total tissue carbohydrate, protein and lipid content of conventionally reared control larvae (at $4^{\text {th }}$ instar stage) were $32.48 \pm 0.88 \mu \mathrm{g} / \mathrm{mg}, 16.89 \pm 0.94 \mu \mathrm{g} / \mathrm{mg}$ and $6.38 \pm 0.31 \mu \mathrm{g} / \mathrm{mg}$ respectively. One way ANOVA revealed that all three biomolecular contents varied significantly among different groups of larvae $(p<0.0001)$. Axenic larvae (at $4^{\text {th }}$ instar stage) had lowest amount of all the biomolecular compounds (carbohydrate, protein \& lipid) in their body $(14.27 \pm 0.76$ $\mu \mathrm{g} / \mathrm{mg}, 7.78 \pm 0.56 \mu \mathrm{g} / \mathrm{mg} \& 2.25 \pm 0.19 \mu \mathrm{g} / \mathrm{mg}$ respectively). Total tissue carbohydrate, protein \& lipid contents were found to be significantly lower in axenic group of larvae that were individually cured with gut bacterial isolates when compared with conventionally reared control group $(p<0.001)$, but all three biomolecules of axenic larvae that were cured with a mixture of all four resident gut bacterial isolates did not show any significant difference when compared with conventionally reared larvae $(p>0.001)$.

\section{Discussion}

The present investigation noted bacterial load in the mid-gut of field collected larvae was higher than laboratory reared group in all the seasons, which indicated that natural habitat water might have some effects in determining bacterial load of mosquito larval gut and that is why gut bacterial load became reduced when cultured in a restricted aquatic environment in laboratory condition. Previous studies by several workers have also indicated that breeding habitats of mosquito play an important role in determining mosquito gut bacterial composition $[45,46]$. Bacteria inhabiting in the habitat water enters in the gut of mosquito larvae through feeding [47]. Further the present study recorded that bacterial load in the mid gut of both field collected and laboratory reared $3^{\text {rd }}$ instar larvae varied in different season throughout the year. Bacterial load was found to be highest in the larval gut during post-monsoon, whereas during winter season bacterial load in the gut of larvae became reduced to a great extent. These observation gives indication that climatic conditions of the environment have a great influence on the bacterial load in the mosquito larval gut. Similar observation was previously reported in case of An. gambiae and An. coluzzii mosquitoes from some urban regions of Ghana, where seasons of the year reported to affect both the diversity and abundances of gut bacteria of mosquitoes [45].

A total of sixteen isolates were recorded in the mid-gut of field collected $3^{\text {rd }}$ instar larvae of An. subpictus, whereas only seven isolates were recorded to be present in the larval mid-gut of laboratory reared mosquitoes throughout different seasons of the year. Among these bacterial isolates, only four isolates (HALG2, HALG4, HALG6 \& HALG7) were found to be present in the mid-gut of both field collected and laboratory reared $3^{\text {rd }}$ instar larvae of An. subpictus.

Page $7 / 29$ 
So, these isolates were supposed to be as the resident gut bacterial flora of larval forms of An. subpictus in the study areas. Identification by polyphasic approach indicated that these isolates were Bacillus subtilis, Bacillus pumilus, Bacillus cereus \& Proteus vulgaris. Some of these bacterial species were reported previously from the gut of different insect species including mosquito, such as Bacillus subtilis was reported in larval gut of Aedes aegypti mosquito [48]; Bacillus pumilus was reported as gut-resident of An. stephensi larvae [49]. Bacillus cereus had been reported as a symbiotic bacterial flora of larval forms of An. subpictus Grassi from Sundarbans areas of West Bengal [13]. Proteus vulgaris was reported in the gut of Bombyx mori larvae [50] and in the hind-gut region of Blatta orientalis [51].

In the present study, antibiotic treatment that clear the bacterial communities from the larval mid-gut, resulted in reduced survival rate, delayed pupation time and reduced total tissue carbohydrate, protein \& lipid contents in the final instar larvae. Further, the body weight \& wing length became reduced in both adult male \& female mosquitoes developed from the axenic group of larvae. Rate of survival up to adult stage and all the development markers (amount of total tissue carbohydrate, protein \& lipid) again became restored only when axenic group of larvae were cured with a mixture of all the resident gut bacteria. No single bacteria could contribute the host development and survival like conventionally reared groups. These results suggested that all the four resident gut bacterial isolates viz., Bacillus subtilis HALG2 (MN894011), Bacillus pumilus HALG4 (MZ363627), Bacillus cereus HALG6 (MZ363632) \& Proteus vulgaris HALG7 (MZ363637) of larval forms of An. subpictus mosquitoes prevalent in rural areas of Hooghly, together contributed in the survival and normal development of their host. These bacterial isolates also have a great impact on body weight and wing length of their host in adult forms. So, it can be considered that these four bacterial isolates have some symbiotic associations with their host. All these findings have indicated that elimination of these symbiotic bacteria from larval gut could impede the development and survival of their host mosquitoes. Similar observations were previously reported by many workers from different regions of the world. Such as, an ampicillin resistant strain of Bacillus sp. was reported from the larval midgut of Anopheles barbirostris mosquito which played a major role during the larval development of this mosquito [52]. They detected that killing of larval gut bacteria by antibiotic treatment, delayed the developmental time of larvae of Anopheles barbirostris. Similarly, in case of An. subpictus, larvae could not develop into adult forms after clearance of symbiotic gut bacteria by antibiotic treatment [13]. Like different species of Anopheles mosquitoes, larvae of Japanese Encephalitis vector Culex vishnui could not survive after removal of one gut bacterial strain (Pseudomonas fluorescens Ps1) [14]. Removal of gut bacterial strains by antibiotic treatment caused in the failure of development beyond $1^{\text {st }}$ instar stage in case of Aedes aegyptiand Aedes atropalpus mosquitoes but recolonization by bacterial strains of breeding habitat water could promote normal development of these two species of mosquitoes [28].

Some previous studies had indicated that biochemical composition and types of foods taken during the larval stages had several impacts on different life cycle stages of adult mosquitoes [53,54]. In the present study, adult male \& female mosquitoes developed from antibiotic treated axenic larvae, had lowest body weight \& smallest wing length. But recolonization of axenic larvae with a mixture of all four resident gut bacterial suspension restored the body weight \& wing length of adult male \& female mosquitoes like that of the conventionally reared groups. All these findings clearly indicated that these four resident gut bacterial isolates (Bacillus subtilis HALG2, Bacillus pumilus HALG4, Bacillus cereus HALG6 \& Proteus vulgaris HALG7) played vital role to sustain the adult morphologies. Similar observations were previously reported in case of Aedes aegypti mosquitoes where larval diets with different bacterial composition had significant effects on pupation time, rate of adult emergence and adult morphology in relation to body weight \& wing length [55].

Bio-chemical analysis indicated that, all these four resident gut bacterial isolates were capable to produce amylase, gelatinase \& lipase enzymes that could degrade starch, gelatin \& lipid content of the medium. Further the carbohydrate fermentation tests showed that the isolates could ferment a number of different carbohydrate sources. Bacillus 
subtilis HALG2 could ferment twelve carbohydrates, Bacillus pumilus HALG4 \& Proteus vulgaris HALG7 could ferment five carbohydrate sources and Bacillus cereus HALG6 was able to ferment three carbohydrate sources. All these biochemical properties of gut bacterial isolates might help their host larvae in food digestion process by degrading a number of carbohydrates, protein \& lipid content of ingested food materials consumed and thus could help in larval digestion process. Earlier studies have reported that food consumption and growth of the insects became reduced after removal of gut bacteria by antibiotic treatment, which clearly indicated that bacteria residing in the gut of insects played vital role in consumption and digestion of food of their host [16].

The biochemical constraints including protein, lipid \& carbohydrate content of body are important markers for assessing any harmful effects on the insects [56]. The present study recorded that total tissue protein, lipid \& carbohydrate content of the antibiotic treated axenic larvae or groups of larvae that were cured with individual bacterial strains were significantly lower than that of the conventionally reared control larvae. But, when the axenic larvae were recolonized with a mixture of all four resident gut bacterial isolates, tissue protein, lipid \& carbohydrate content showed no significant differences with conventionally reared control larval groups. These findings have suggested that all these four gut bacterial isolates are the key players for maintaining the healthy development of their hosts.

Growth of the gut bacterial isolates at different $\mathrm{pH}$ of the media indicated that their optimum $\mathrm{pH}$ for growth was around 7.5, which indicated that slightly alkaline gut environment of mosquito larvae could provide appropriate environment for the growth of these bacterial species. Temperature tolerance tests indicated that, all the four gut bacterial isolates could tolerate a wide range of environmental temperature $\left(15^{\circ} \mathrm{C}-45^{\circ} \mathrm{C}\right)$ and their growth enhanced when the temperature was around $30^{\circ} \mathrm{C}$. The suitable larval gut microenvironmental conditions in relation to the growth of these bacterial isolates might help them to survive within the host body and to perform a key role in the development of their hosts.

\section{Conclusion}

The present study has identified four bacterial species namely Bacillus subtilis HALG2, Bacillus pumilus HALG4, Bacillus cereus HALG6 \& Proteus vulgaris HALG7 as symbiotic larval gut bacteria of malarial vector Anopheles subpictus in the rural areas of Hooghly district, West Bengal, India. All these four isolates together contributed the larval survival, development and health of adult male \& female mosquitoes. So, management or control of these bacteria from mosquito larval gut could inhibit larval survival and development, which might generate an alternative strategy of vector control programme.

\section{Declarations}

\section{Acknowledgements}

The authors are thankful to the Burdwan University authority for providing laboratory facilities to carry out the work. The authors are thankful to Zoological Survey of India for the identification of mosquito specimens. The authors are also thankful to University Grant Commission (UGC, India) and WBDSTBT, Govt. of West Bengal for providing financial support. Authors are also very much thankful to DST PURSE, DST FIST for providing instrumental facilities.

Funding This research was supported by funding from University Grant Commission, India and WBDSTBT, Govt. of West Bengal.

Conflict of interest/ Competing interest The authors declare that there is no conflict of interest. 
Availability of data and material Mosquitoes were collected by the authors along with the help of field collectors from rural areas of Hooghly, West Bengal, India. The data were collected from the experiments done by the authors in the Parasitology \& Microbiology Research Laboratory, Department of Zoology, The University of Burdwan.

\section{Code availability Nil}

Authors' contribution Author Madhurima Seal conducted all the experiments, analysed the data and wrote the first draft of manuscript. Author Soumendranath Chatterjee designed the work, supervised all the experiments conducted, revised and edited the manuscript. Both the authors red and approved the final version of the manuscript.

\section{Ethics approval NA}

Consent to participate All of the authors consent to participate.

Consent for publication The authors hereby give full consent for publication of the data.

\section{References}

1. Derua, Y. A., Rumisha, S. F., Batengana, B. M., Max, D. A., Stanley, G., Kisinza, W. N., \& Mboera, L. E. (2017). Lymphatic filariasis transmission on Mafia Islands, Tanzania: evidence from xenomonitoring in mosquito vectors. PLoS neglected tropical diseases, 11(10), e0005938.

2. Bartilol, B., Omedo, I., Mbogo, C., Mwangangi, J., \& Rono, M. K. (2021). Bionomics and ecology of Anopheles merus along the East and Southern Africa coast. Parasites \& vectors, 14(1), 1-11.

3. Soleimani Ahmadi, M., Vatandoost, H., Shaeghi, M., Raeisi, A., Abedi, F., Eshraghian, M. R., ... \& PoorahmadGarbandi, F. (2012). Vector ecology and susceptibility in a malaria-endemic focus in southern Islamic Republic of Iran. Eastern Mediterranean Health Journal, 18 (10), 1034-1041.

4. Feltelius, V., \& Elleby, R. (2014). Habitat characterization for malaria vector mosquito larvae in Gamo Gofa, Ethiopia. (Dissertation). Retrieved from http://urn.kb.se/resolve?urn=urn:nbn:se:uu:diva-233924

5. Russel, P.F., West, L.S., Manwell, R.D. \& Macdonald, G. (1963). Practical Malariology 2nd ed. Oxford University Press, London, 44, 275.

6. Panicker, K.N., Geetha Bai, M., Bheema Rao, U.S., Viswam, K. \& Suryanarayanmurthy, U. (1981). Anopheles subpictus, vector of malaria in coastal villages of South-East India. Current Science, 50, 694-695.

7. Hearth, P. R. J., Abhayawardana, T.A. and Padmelal, U. K.G.K. (1983). A study of the role of different anopheline species in the transmission of human malaria in Sri Lanka. Proceedings of Annual Session of Sri Lanka. Assoc. Adv. Sci., 39, 6.

8. Chatterjee, S., \& Chandra, G. (2000). Role of Anopheles subpictus as a primary vector of malaria in an area in India. Japanese Journal of Tropical Medicine and Hygiene, 28(3), 177-181.

9. Mills, J. N., Gage, K. L., \& Khan, A. S. (2010). Potential influence of climate change on vector-borne and zoonotic diseases: a review and proposed research plan. Environmental health perspectives, 118(11), 1507-1514.

10. De Boer, J. G., Robinson, A., Powers, S. J., Burgers, S. L., Caulfield, J. C., Birkett, M. A., ... \& Logan, J. G. (2017). Odours of Plasmodium falciparum-infected participants influence mosquito-host interactions. Scientific reports, $7(1), 1-9$.

11. Lefevre, T., Ohm, J., Dabire, K. R., Cohuet, A., Choisy, M., Thomas, M. B., \& Cator, L. (2018). Transmission traits of malaria parasites within the mosquito: Genetic variation, phenotypic plasticity, and consequences for control. Evolutionary applications, 11(4), 456-469. 
12. Kikuchi, Y., Hosokawa, T., Nikoh, N., Meng, X. Y., Kamagata, Y., \& Fukatsu, T. (2009). Host-symbiont co-speciation and reductive genome evolution in gut symbiotic bacteria of acanthosomatid stinkbugs. BMC Biology, 7(1), 1-22.

13. Mukhopadhyay, P., \& Chatterjee, S. (2016). Characterization and control of symbiotic Bacillus cereus isolated from the mid gut of Anopheles subpictus Grassi. Journal of Parasitic Diseases, 40(4), 1414-1421.

14. Roy, M., Chatterjee, S. N., Roy, P., \& Dangar, T. K. (2010). Significance of the midgut bacterium Pseudomonas fluorescens on Culex vishnui (Diptera: Culicidae) larval development. International Journal of Tropical Insect Science, 30(4), 182-185.

15. Fouda, M.A., Hassan, M.I., Al-Daly, A.G., Hammad, K.M. (2001). Effect of midgut bacteria of Culex pipiens L. on digestion and reproduction. Journal of the Egyptian Society of Parasitology, 31(3):767-780.

16. Xia, X., Lan, B., Tao, X., Lin, J., \& You, M. (2020). Characterization of Spodoptera litura gut bacteria and their role in feeding and growth of the host. Frontiers in microbiology, 11, 1-14.

17. Douglas, A. E. (1998). Nutritional interactions in insect-microbial symbioses: aphids and their symbiotic bacteria Buchnera. Annual review of entomology, 43(1), 17-37.

18. Crotti, E., Rizzi, A., Chouaia, B., Ricci, I., Favia, G., Alma, A., ... \& Daffonchio, D. (2010). Acetic acid bacteria, newly emerging symbionts of insects. Applied and Environmental Microbiology, 76(21), 6963-6970.

19. Pais, R., Lohs, C., Wu, Y., Wang, J., \& Aksoy, S. (2008). The obligate mutualist Wigglesworthia glossinidia influences reproduction, digestion, and immunity processes of its host, the Tsetse fly. Applied and environmental microbiology, 74(19), 5965-5974.

20. Pang, X., Xiao, X., Liu, Y., Zhang, R., Liu, J., Liu, Q., ... \& Cheng, G. (2016). Mosquito C-type lectins maintain gut microbiome homeostasis. Nature microbiology, 1(5), 1-11.

21. Bahia, A. C., Dong, Y., Blumberg, B. J., Mlambo, G., Tripathi, A., BenMarzouk-Hidalgo, O. J., ... \& Dimopoulos, G. (2014). Exploring Anopheles gut bacteria for Plasmodium blocking activity. Environmental microbiology, 16(9), 2980-2994.

22. Straif, S. C., Mbogo, C. N., Toure, A. M., Walker, E. D., Kaufman, M., Toure, Y. T., \& Beier, J. C. (1998). Midgut bacteria in Anopheles gambiae and An. funestus (Diptera: Culicidae) from Kenya and Mali. Journal of medical entomology, 35(3), 222-226.

23. Lindh, J. M., Terenius, O., \& Faye, I. (2005). 16S rRNA gene-based identification of midgut bacteria from fieldcaught Anopheles gambiae sensu lato and $A$. funestus mosquitoes reveals new species related to known insect symbionts. Applied and environmental microbiology, 71(11), 7217-7223.

24. Briones, A. M., Shililu, J., Githure, J., Novak, R., \& Raskin, L. (2008). Thorsellia anophelis is the dominant bacterium in a Kenyan population of adult Anopheles gambiae mosquitoes. The ISME journal, 2(1), 74-82.

25. Wang, Y., Gilbreath III, T. M., Kukutla, P., Yan, G., \& Xu, J. (2011). Dynamic gut microbiome across life history of the malaria mosquito Anopheles gambiae in Kenya. PLoS ONE, 6(9), e24767.

26. Boissiere, A., Tchioffo, M. T., Bachar, D., Abate, L., Marie, A., Nsango, S. E., ... \& Morlais, I. (2012). Midgut microbiota of the malaria mosquito vector Anopheles gambiae and interactions with Plasmodium falciparum infection. PLoS pathogens, 8(5), e1002742.

27. Chavshin, A. R., Oshaghi, M. A., Vatandoost, H., Pourmand, M. R., Raeisi, A., \& Terenius, O. (2014). Isolation and identification of culturable bacteria from wild Anopheles culicifacies, a first step in a paratransgenesis approach. Parasites \& vectors, 7(1), 1-8.

28. Ngo, C. T., Aujoulat, F., Veas, F., Jumas-Bilak, E., \& Manguin, S. (2015). Bacterial diversity associated with wild caught Anopheles mosquitoes from Dak Nong Province, Vietnam using culture and DNA fingerprint. PLoS One, 10(3), e0118634. 
29. Coon, K. L., Brown, M. R., \& Strand, M. R. (2016). Gut bacteria differentially affect egg production in the anautogenous mosquito Aedes aegypti and facultatively autogenous mosquito Aedes atropalpus (Diptera: Culicidae). Parasites \& vectors, 9(1), 1-12.

30. World Health Organization. (1992). Report of the WHO Expert Committee on filariasis. Technical Representative, 821:1-30.

31. Service, W.M. (1993). Mosquito ecology: field sampling methods. Chapman and Hall, London, 1-988.

32. Tyagi, B. K., Munirathinam, A., \& Venkatesh, A. (2015). A catalogue of Indian mosquitoes. International Journal of Mosquito Research, 2(2), 50-97.

33. Nagpal, B.N., \& Sharma, V, P. (1995). Indian anophelines. Oxford \& IBH Publishing Co. Pvt. Ltd, New Delhi, 1-416.

34. Pelczar, M.J., Bard, R.C., Burnett, G.W., Conn, H.J., Demoss, R.D., Euans. E.E., Weiss, F.A., Jennison, M.W., Meckee, A.P., Riker, A.J., Warren, J., \& Weeks, O.B. (1957). Manual of microbiological methods. Society of American Bacteriology. McGraw Hill Book Company, Inc., NY, USA, 315.

35. Collee, J.G. \& Miles, P.S. (1989). Tests for identification of bacteria. In: Practical medical microbiology, Eds. Collee JG, Duguid JP, Fraser AG, Marmion BP. Churchil Livingstone, NY, USA, 141-160.

36. Lacey, L.A. (1997). Manual of techniques in Insect pathology. Acad. Press, NY, USA, 409.

37. Jansen, J.F., de Brabander-van den Berg E. M. M., \& Meijer, E.W. (1994). Encapsulation of guest molecules into a dendritic box. Science 266(5188):1226-1229.

38. Saitou, N., \& Nei, M. (1987). The neighbor-joining method: a new method for reconstructing phylogenetic trees. Molecular Biology and Evolution, 4, 406-425.

39. Brown, A.E. (2005). Benson's microbiological applications: laboratory manual in general microbiology. McGrawHill Higher Education.

40. Shibko, S., Koivistoinen, P., Tratnyek, C. A., Newhall, A. R., \& Friedman, L. (1967). A method for sequential quantitative separation and determination of protein, RNA, DNA, lipid, and glycogen from a single rat liver homogenate or from a subcellular fraction. Analytical biochemistry, 19(3), 514-528.

41. Nestel, D., Tolmasky, D., Rabossi, A., \& Quesada-Allue, L. A. (2003). Lipid, carbohydrates and protein patterns during metamorphosis of the Mediterranean fruit fly, Ceratitis capitata (Diptera: Tephritidae). Annals of the Entomological Society of America, 96(3), 237-244.

42. Warburg, M. S., \& Yuval, B. (1997). Effects of energetic reserves on behavioral patterns of Mediterranean fruit flies (Diptera: Tephritidae). Oecologia, 112(3), 314-319.

43. Zhen, Y., \& Shi, J. (2011). Evaluation of sample extraction methods for proteomic analysis of coniferous seeds. Acta physiologiae plantarum, 33(5), 1623-1630.

44. Lowry, O. H., Rosebrough, N. J., Farr, A. L., \& Randall, R. J. (1951). Protein measurement with the Folin phenol reagent. Journal of biological chemistry, 193, 265-275.

45. Akorli, J., Gendrin, M., Pels, N. A. P., Yeboah-Manu, D., Christophides, G. K., \& Wilson, M. D. (2016). Seasonality and locality affect the diversity of Anopheles gambiae and Anopheles coluzzii midgut microbiota from Ghana. PLoS ONE, 11(6), e0157529.

46. Bascunan, P., Nino-Garcia, J. P., Galeano-Castaneda, Y., Serre, D., \& Correa, M. M. (2018). Factors shaping the gut bacterial community assembly in two main Colombian malaria vectors. Microbiome, 6(1), 1-12.

47. Minakawa, N., Munga, S., Atieli, F., Mushinzimana, E., Zhou, G., Githeko, A. K., \& Yan, G. (2005). Spatial distribution of anopheline larval habitats in Western Kenyan highlands: effects of land cover types and topography. The American journal of tropical medicine and hygiene, 73(1), 157-165. 
48. Gusmao, D. S., Santos, A. V., Marini, D. C., Russo, E. D. S., Peixoto, A. M. D., Bacci Junior, M., ... \& Lemos, F. J. A. (2007). First isolation of microorganisms from the gut diverticulum of Aedes aegypti (Diptera: Culicidae): new perspectives for an insect-bacteria association. Memorias do Instituto Oswaldo Cruz, 102(8), 919-924.

49. Dinparast Djadid, N., Jazayeri, H., Raz, A., Favia, G., Ricci, I., \& Zakeri, S. (2011). Identification of the midgut microbiota of An. stephensi and An. maculipennis for their application as a paratransgenic tool against malaria. PLOS ONE, 6(12), e28484.

50. Anand, A. A. P., Vennison, S. J., Sankar, S. G., Gilwax Prabhu, D. I., Vasan, P. T., Raghuraman, T., ... \& Vendan, S. E. (2010). Isolation and characterization of bacteria from the gut of Bombyx mori that degrade cellulose, xylan, pectin and starch and their impact on digestion. Journal of Insect Science, 10(1), 1-20.

51. Burgess, N. R. H., McDermott, S. N., \& Whiting, J. (1973). Aerobic bacteria occurring in the hind-gut of the cockroach, Blatta orientalis. Epidemiology \& Infection, 71(1), 1-8.

52. Chatterjee, S., \& Ghosh, T. S. (2010). Characterization of ampicillin resistant Bacillus sp. isolated from the midgut of Anopheles barbirostris (Van der Wulp) and its role on larval development. Journal of Pure and Applied Microbiology, 4(2), 875-878.

53. Suwanchaichinda, C., \& Paskewitz, S. M. (1998). Effects of larval nutrition, adult body size, and adult temperature on the ability of Anopheles gambiae (Diptera: Culicidae) to melanize Sephadex beads. Journal of medical entomology, 35(2), 157-161.

54. Linenberg, I., Christophides, G. K., \& Gendrin, M. (2016). Larval diet affects mosquito development and permissiveness to Plasmodium infection. Scientific reports, 6(1), 1-10.

55. Souza, R. S., Virginio, F., Riback, T. I. S., Suesdek, L., Barufi, J. B., \& Genta, F. A. (2019). Microorganism-based larval diets affect mosquito development, size and nutritional reserves in the yellow fever mosquito Aedes aegypti (Diptera: Culicidae). Frontiers in physiology, 10, 1-24.

56. Sharma, P., Mohan, L., Dua, K. K., \& Srivastava, C. N. (2011). Status of carbohydrate, protein and lipid profile in the mosquito larvae treated with certain phytoextracts. Asian Pacific journal of tropical medicine, 4(4), 301-304.

\section{Tables}

Table 1. Season-wise bacterial load in the mid-gut of $3^{\text {rd }}$ instar larvae of Anopheles subpictus mosquitoes (March'2017-February'2018).

\begin{tabular}{lll} 
Season & \multicolumn{2}{l}{$\mathrm{Cfu} / \mathrm{mL}$} \\
\cline { 2 - 3 } & \multicolumn{1}{c}{ Field collected } & Laboratory reared \\
\hline Summer & $10.5 \pm 0.72 \times 10^{6}$ & $8.4 \pm 0.66 \times 10^{4}$ \\
\hline Monsoon & $24.13 \pm 1.3 \times 10^{6}$ & $12.8 \pm 0.60 \times 10^{5}$ \\
\hline Post-monsoon & $16.26 \pm 1.1 \times 10^{7}$ & $19 \pm 2.5 \times 10^{5}$ \\
& & \\
\hline Winter & $8.6 \pm 0.40 \times 10^{5}$ & $8 \pm 0.67 \times 10^{4}$
\end{tabular}


Values are averages (Mean \pm S.E) of three replicates.

Table 2. Colony characteristics of resident gut bacterial isolates of $3^{\text {rd }}$ instar larvae of Anopheles subpictus mosquito.

SI Name of Colony characters

No. isolates

\begin{tabular}{|c|c|c|c|c|c|c|c|c|}
\hline & & Shape & $\begin{array}{l}\text { Size }(\mathrm{mm}) \\
\text { (MeantSD) }\end{array}$ & Opacity & Elevation & Consistency & Margin & Colour \\
\hline 1 & HALG2 & Round & $2.10 \pm 0.15$ & Opaque & Flat & Dry & Irregular & White \\
\hline 2 & HALG4 & Round & $1.72 \pm 0.28$ & Opaque & Flat & Moist & Irregular & $\begin{array}{l}\text { Off } \\
\text { white }\end{array}$ \\
\hline 3 & HALG6 & Round & $2.52 \pm 0.39$ & Opaque & $\begin{array}{l}\text { Slightly } \\
\text { elevated }\end{array}$ & Moist & Smooth & $\begin{array}{l}\text { Off } \\
\text { white }\end{array}$ \\
\hline 4 & HALG7 & Round & $2.78 \pm 0.19$ & Opaque & Elevated & Sticky & Smooth & $\begin{array}{l}\text { Glossy } \\
\text { white }\end{array}$ \\
\hline
\end{tabular}

Table 3. Staining properties of resident gut bacterial isolates of $3^{\text {rd }}$ instar larvae of Anopheles subpictus mosquito.

\begin{tabular}{llll}
\multirow{2}{*}{ Name of the Isolates } & \multicolumn{2}{l}{ Gram's Stain } & Endospore \\
\cline { 2 - 3 } & Property & Shape of Vegetative cells & \\
\hline HALG2 & Positive & Rods single & Present \\
\hline HALG4 & Positive & Rods single & Present \\
\hline HALG6 & Positive & Rods single or in short chain & Present \\
\hline HALG7 & Negative & Rods single & Absent
\end{tabular}

Table 4. Bio-chemical characteristics of the resident bacterial isolates from the mid-gut of $3^{\text {rd }}$ instar larvae of Anopheles subpictus. 


\begin{tabular}{|c|c|c|c|c|}
\hline \multirow{2}{*}{$\begin{array}{l}\text { Name of the } \\
\text { biochemical tests }\end{array}$} & \multicolumn{4}{|c|}{ Name of the bacterial isolates } \\
\hline & HALG2 & HALG4 & HALG6 & HALG7 \\
\hline Catalase production & + & + & + & + \\
\hline Indole production & - & - & - & + \\
\hline Methyl Red (MR) & - & - & + & + \\
\hline Voges Proskauer (VP) & - & - & - & - \\
\hline Citrate utilization & - & - & - & - \\
\hline Nitrate reduction & + & - & + & + \\
\hline Oxidase production & - & + & + & - \\
\hline Urease production & - & - & - & + \\
\hline Starch hydrolysis & + & + & + & + \\
\hline Lipid hydrolysis & + & + & + & + \\
\hline Gelatine hydrolysis & + & + & + & + \\
\hline Motility & + & + & + & + \\
\hline Triple Sugar Iron Agar (TSI) & AVA & AVA, G & K/A & KJA \\
\hline $\mathrm{H}_{2} \mathrm{~S}$ production & - & - & - & + \\
\hline
\end{tabular}

+= Positive, -=Negative, K=Alkaline, A=Acidic, $G=$ Gas

Table 5. Carbohydrate fermentation tests of gut bacterial isolates of $3^{\text {rd }}$ instar larvae of Anopheles subpictus. 


\begin{tabular}{|c|c|c|c|c|}
\hline Carbohydrate source & HALG2 & HALG4 & HALG6 & HALG7 \\
\hline Dextrose (De) & + & + & + & + \\
\hline Sucrose (Su) & + & + & - & + \\
\hline Lactose (La) & - & - & - & - \\
\hline Trehalose (Te) & + & + & + & + \\
\hline Fructose (Fc) & + & + & + & + \\
\hline Galactose (Ga) & - & - & - & - \\
\hline Inositol (IS) & + & - & - & - \\
\hline Arabinose (Ar) & + & - & - & - \\
\hline Mannitol (Mn) & + & - & - & - \\
\hline Cellobiose (Ce) & + & + & - & - \\
\hline Melibiose (Mb) & - & - & - & - \\
\hline Dulcitol (Du) & - & - & - & - \\
\hline Xylose (Xy) & - & - & - & + \\
\hline Adonitol (Ad) & - & - & - & - \\
\hline Rhamnose (Rh) & - & - & - & - \\
\hline Sorbitol (Sb) & + & - & - & - \\
\hline Raffinose (Rf) & + & - & - & - \\
\hline Mannose (Mo) & + & - & - & - \\
\hline Salicin (Sa) & - & - & - & - \\
\hline Inulin (In) & + & - & - & - \\
\hline
\end{tabular}

' + ' indicate positive for fermentation, '-' indicates negative result for fermentation

Table 6. Antibiotic sensitivity of resident gut bacteria $3^{\text {rd }}$ instar larvae of Anopheles subpictus. 


\begin{tabular}{|c|c|c|c|c|c|c|c|c|}
\hline \multirow[t]{2}{*}{ Antibiotics } & \multicolumn{2}{|c|}{ B. subtilis HALG2 } & \multicolumn{2}{|c|}{ B. pumilus HALG4 } & \multicolumn{2}{|c|}{ B. cereus HALG6 } & \multicolumn{2}{|c|}{ P. vulgaris HALG7 } \\
\hline & Sensitivity & $\begin{array}{l}\text { ZDI } \\
(\mathrm{mm})\end{array}$ & Sensitivity & $\begin{array}{l}\text { ZDI } \\
(\mathrm{mm})\end{array}$ & Sensitivity & $\begin{array}{l}\text { ZDI } \\
(\mathrm{mm})\end{array}$ & Sensitivity & $\begin{array}{l}\text { ZDI } \\
(\mathrm{mm})\end{array}$ \\
\hline Chloramphenicol $(\mathrm{C}, 30)$ & $\mathbf{s}$ & 23 & $s$ & 18 & $s$ & 20 & $\mathbf{s}$ & 18 \\
\hline Kanamycin $(K, 30)$ & s & 24 & s & 26 & s & 20 & s & 25 \\
\hline Levofloxacin (LE,5) & $\mathbf{s}$ & 40 & $\mathbf{s}$ & 38 & $\mathbf{s}$ & 28 & $\mathbf{s}$ & 35 \\
\hline Gentamicin (GEN,50) & $\mathrm{s}$ & 32 & $s$ & 29 & $\mathbf{s}$ & 26 & $s$ & 31 \\
\hline Neomycin $(N, 30)$ & $\mathbf{s}$ & 28 & $\mathbf{s}$ & 25 & $\mathbf{s}$ & 20 & s & 27 \\
\hline Bacitracin $(B, 10)$ & $s$ & 9 & $s$ & 12 & $s$ & 13 & $s$ & 10 \\
\hline Ofloxacin $(O F, 5)$ & s & 32 & $s$ & 34 & $s$ & 24 & $s$ & 31 \\
\hline Norfloxacin $(N X, 10)$ & S & 36 & S & 30 & S & 24 & S & 31 \\
\hline Tetracycline (TE,30) & S & 30 & s & 36 & S & 25 & S & 27 \\
\hline Ciprofloxacin (CIP, 5) & s & 40 & s & 36 & $s$ & 29 & $s$ & 34 \\
\hline Vancomycin (VA, 30) & $s$ & 21 & $s$ & 27 & $s$ & 19 & $s$ & 23 \\
\hline Rifampicin (RIF,5) & S & 16 & $\mathbf{s}$ & 17 & $\mathbf{s}$ & 13 & S & 26 \\
\hline Azithromycin (AZM,30) & $\mathbf{s}$ & 34 & $s$ & 29 & $s$ & 23 & $s$ & 29 \\
\hline Erythromycin $(E, 15)$ & $\mathbf{s}$ & 28 & $\mathbf{s}$ & 23 & $\mathbf{s}$ & 25 & $s$ & 27 \\
\hline Amoxicillin (AMX,10) & s & 40 & S & 21 & $\mathbf{R}$ & Nil & s & 40 \\
\hline Ampicillin (AMP,10) & $\mathbf{R}$ & Nil & $\mathbf{R}$ & Nil & $\mathbf{R}$ & Nil & $\mathbf{R}$ & Nil \\
\hline Penicillin $(\mathrm{P}, 10)$ & $\mathbf{R}$ & Nil & $\mathbf{R}$ & Nil & $\mathbf{R}$ & Nil & $\mathbf{R}$ & Nil \\
\hline Streptomycin $(S, 10)$ & $\mathbf{R}$ & Nil & $\mathbf{s}$ & 25 & $\mathbf{s}$ & 22 & $\mathbf{s}$ & 24 \\
\hline Doxycycline $(\mathrm{DO}, 30)$ & s & 30 & s & 33 & s & 24 & s & 30 \\
\hline Nalidixic acid $(\mathrm{NA}, 30)$ & $s$ & 23 & $s$ & 26 & $s$ & 20 & $s$ & 24 \\
\hline
\end{tabular}

\section{S= Sensitive, $\mathrm{R}=$ Resistant}

Table 7. Minimum Inhibitory Concentration of standard antibiotics against bacterial isolates.

Name of isolates Doxycycline $(\mu \mathrm{g} / \mathrm{mL})$ Levofloxacin $(\mu \mathrm{g} / \mathrm{mL})$

\begin{tabular}{lll} 
HALG2 & 0.125 & 0.32 \\
\hline HALG4 & 0.16 & 0.09 \\
\hline HALG6 & 0.40 & 0.25 \\
\hline HALG7 & 0.75 & 0.30
\end{tabular}


Table 8. Total cellular carbohydrate, protein and lipid content of different groups of $4^{\text {th }}$ instar larvae of Anopheles subpictus.

\begin{tabular}{|llll|}
\hline Treatment & $\begin{array}{l}\text { Carbohydrate } \\
(\mu \mathrm{g} / \mathrm{mg})\end{array}$ & $\begin{array}{l}\text { Protein } \\
(\mu \mathrm{g} / \mathrm{mg})\end{array}$ & $\begin{array}{l}\text { Lipid } \\
(\mu \mathrm{g} / \mathrm{mg})\end{array}$ \\
\hline Axenic & $14.27 \pm 0.76$ & $7.78 \pm 0.56$ & $2.25 \pm 0.19$ \\
\hline HALG2 & $20.06 \pm 0.86$ & $8.14 \pm 0.53$ & $3.58 \pm 0.29$ \\
\hline HALG4 & & & \\
\hline HALG6 & $19.91 \pm 0.93$ & $7.97 \pm 0.40$ & $4.11 \pm 0.21$ \\
& & & \\
\hline HALG7 & $20.81 \pm 0.98$ & $13.9 \pm 0.62$ & $4.72 \pm 0.26$ \\
\hline All four isolates & $28.08 \pm 0.78$ & $15.07 \pm 0.40$ & $5.05 \pm 0.42$ \\
\hline Conventionally reared & $32.48 \pm 0.88$ & $16.89 \pm 0.94$ & $6.38 \pm 0.31$ \\
\hline & & & \\
\hline
\end{tabular}

Values are averages (Mean \pm SE) of five replications.

\section{Figures}




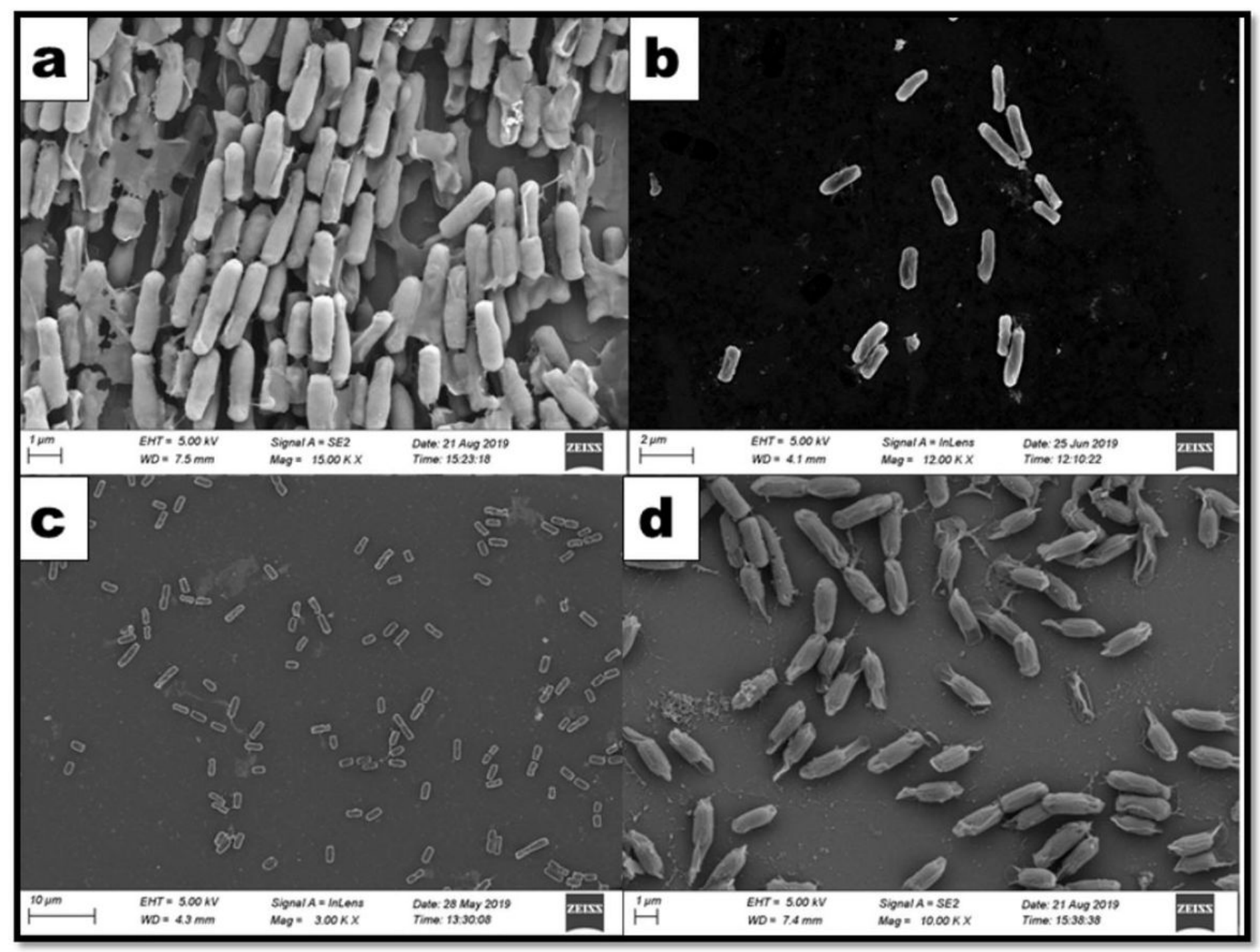

Figure 1

Scanning electron micrograph showing vegetative bodies of the bacterial isolates (a: Bacillus subtilis HALG2, b: Bacillus pumilus HALG4, c: Bacillus cereus HALG6, d: Proteus vulgaris HALG7). 


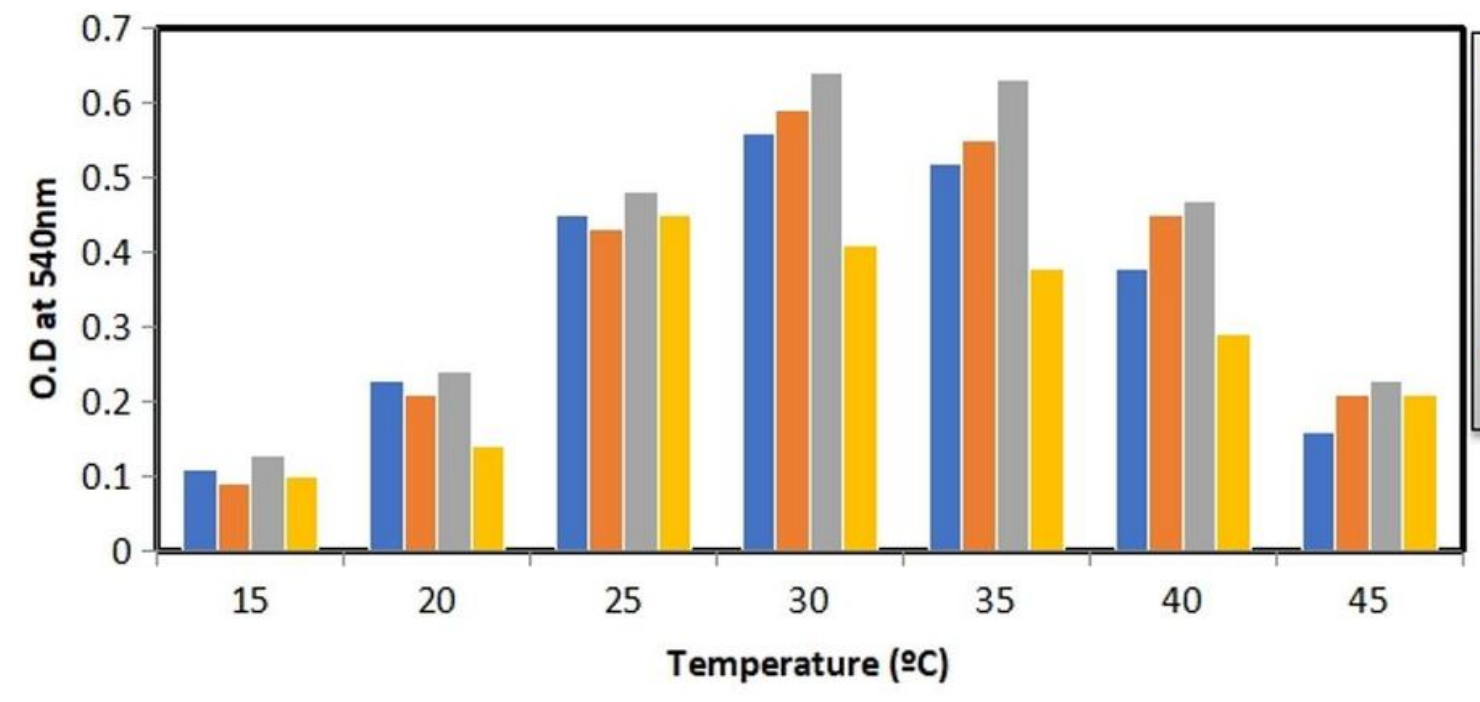

Bacillus subtilis HALG2

Bacillus pumilus HALG4

Bacillus cereus HALG6

Proteus vulgaris HALG7

Figure 2

Growth of bacterial isolates at different $\mathrm{pH}$ of the media.

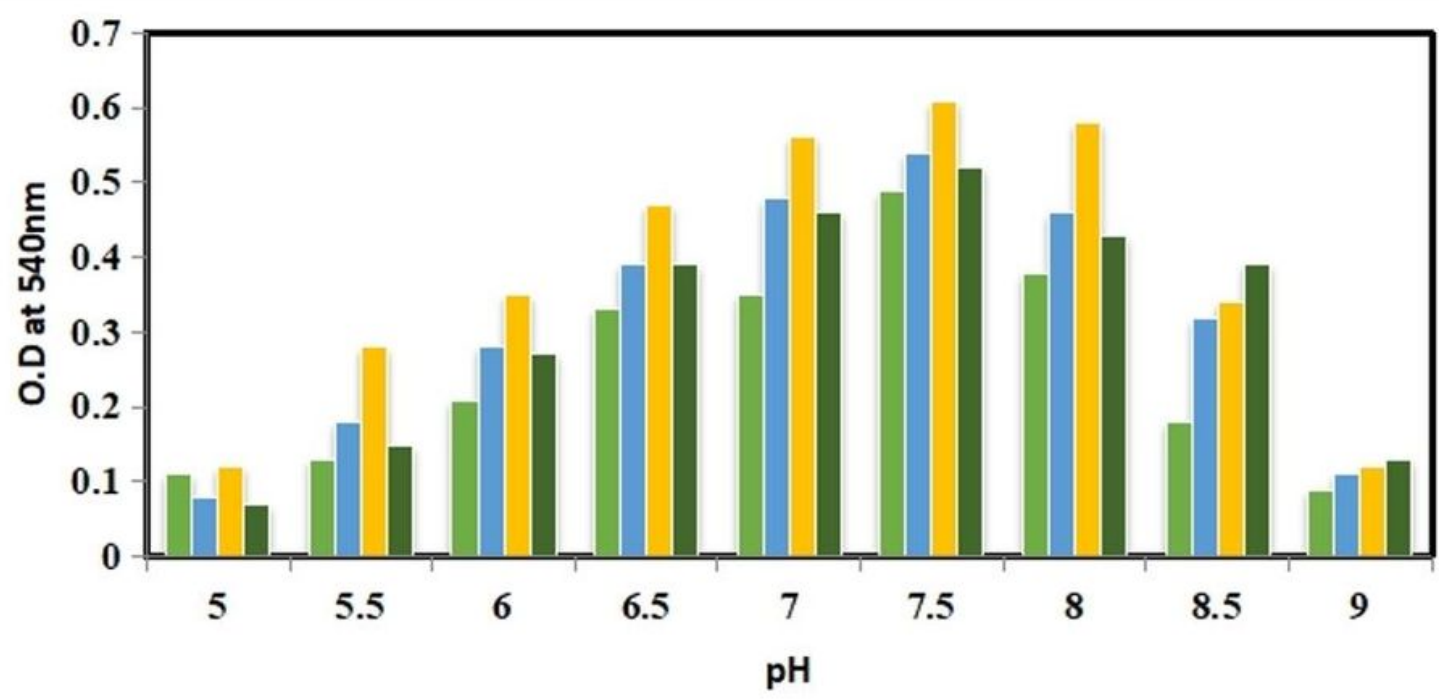

Bacillus subtilis HALG2

Bacillus pumilus HALG4

Bacillus cereus HALG6

$\square$ Proteus vulgaris HALG7

Figure 3

Growth of bacterial isolates at different temperature. 


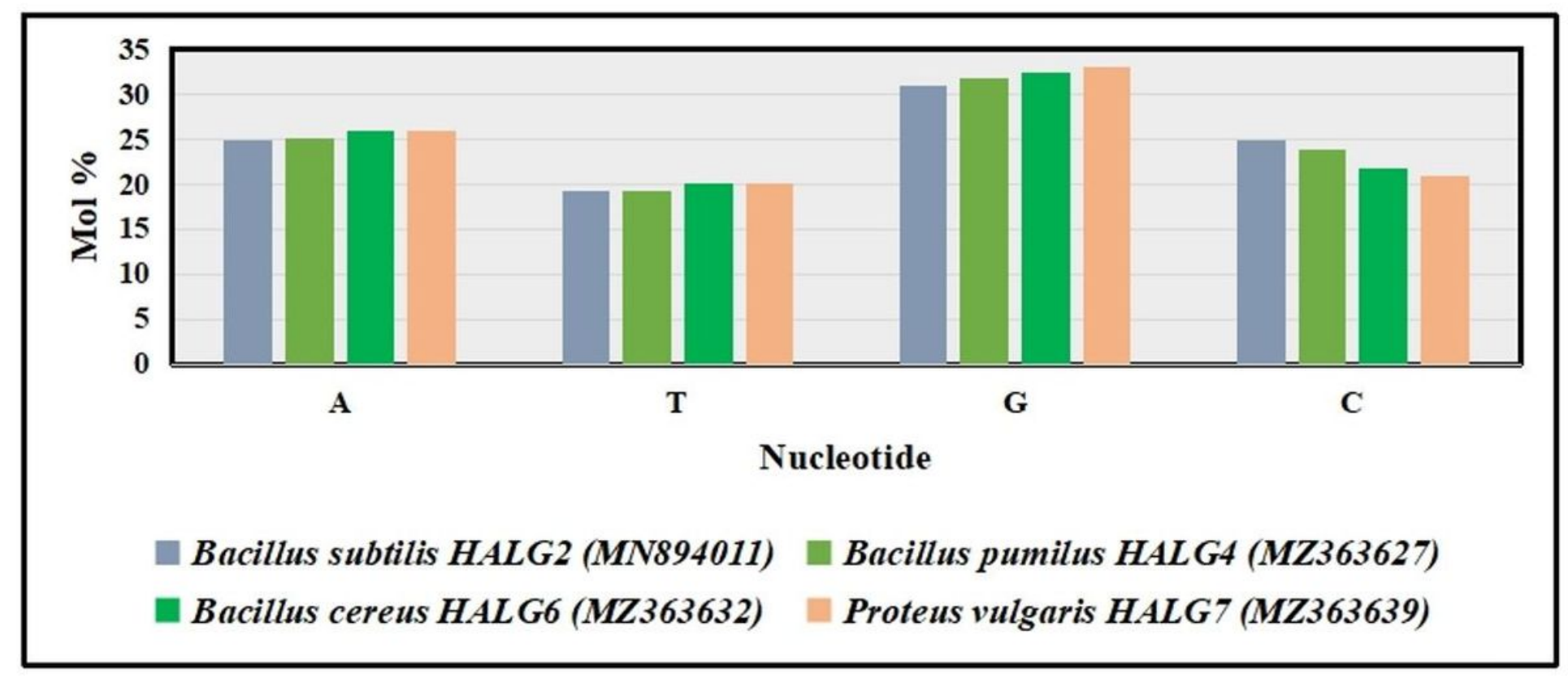

Figure 4

Nucleotide composition of 16S rRNA gene sequences of resident gut bacterial isolates of larvae of Anopheles subpictus. 


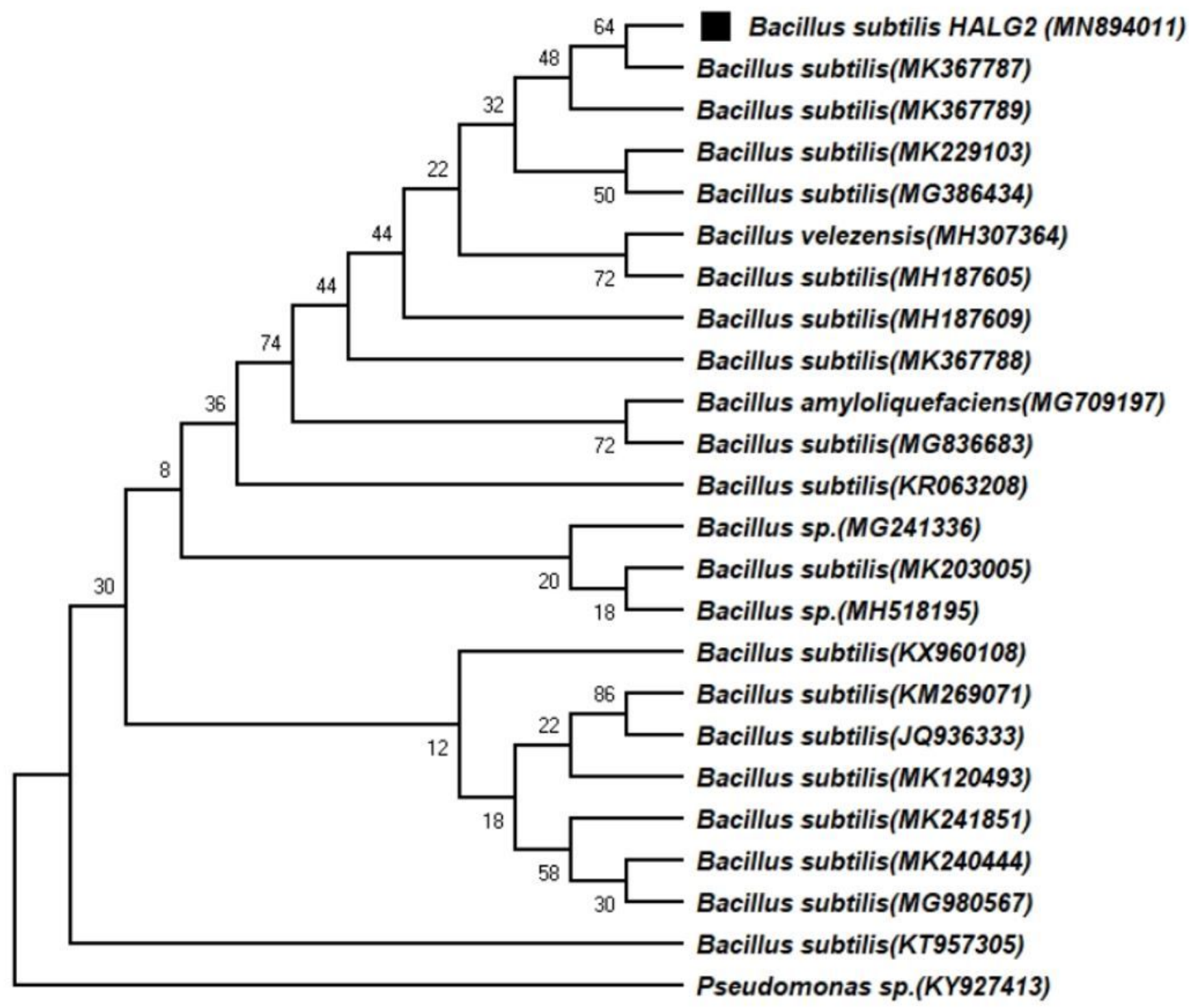

Figure 5

Phylogenetic tree constructed based on partial 16S rRNA gene sequence of HALG2 (MN894011) strain along with the other 16S rRNA gene sequences retrieved from NCBI and RDP. 


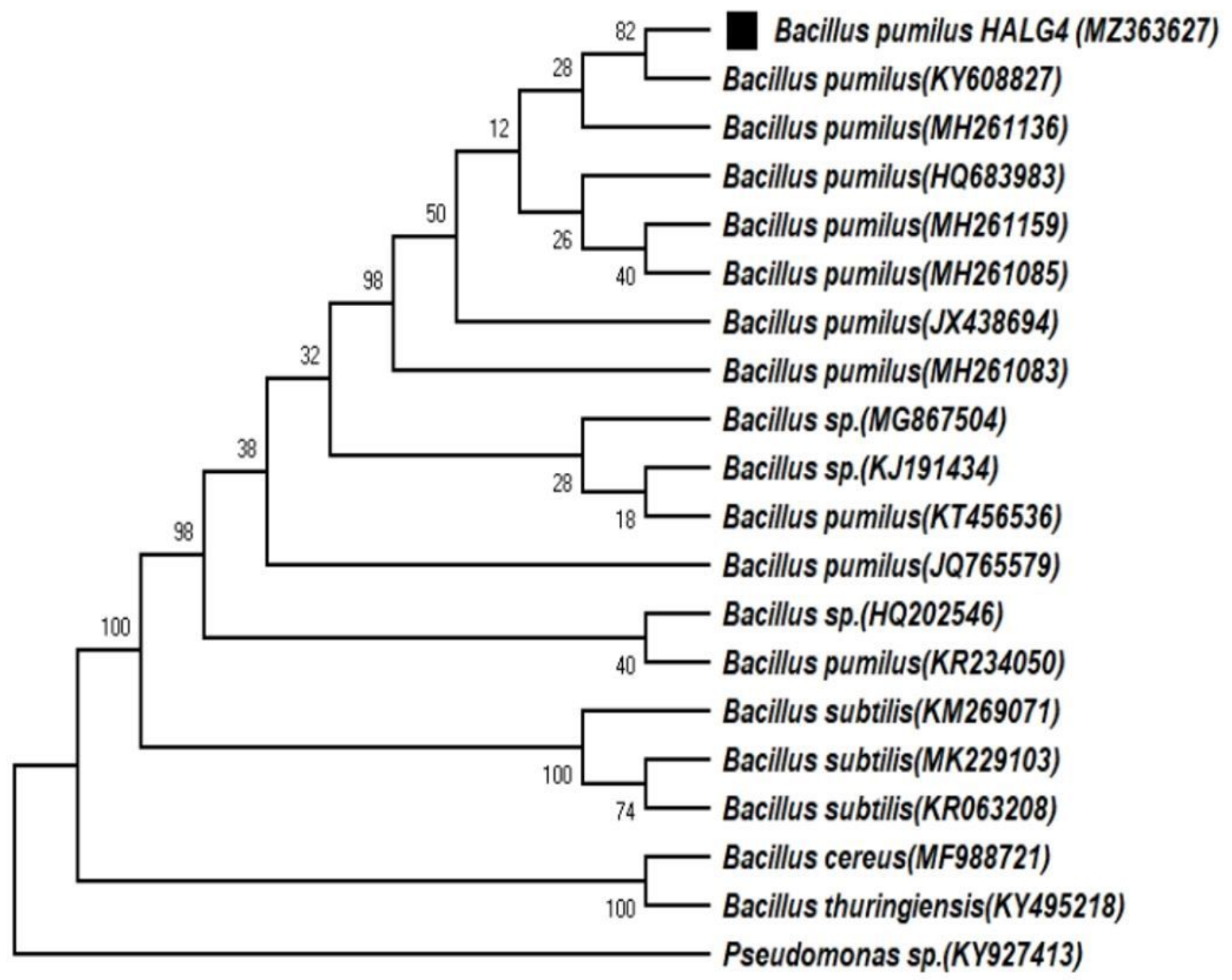

Figure 6

Phylogenetic tree constructed based on partial 16S rRNA gene sequence of HALG4 (MZ363627) strain along with the other 16S rRNA gene sequences retrieved from NCBI and RDP. 


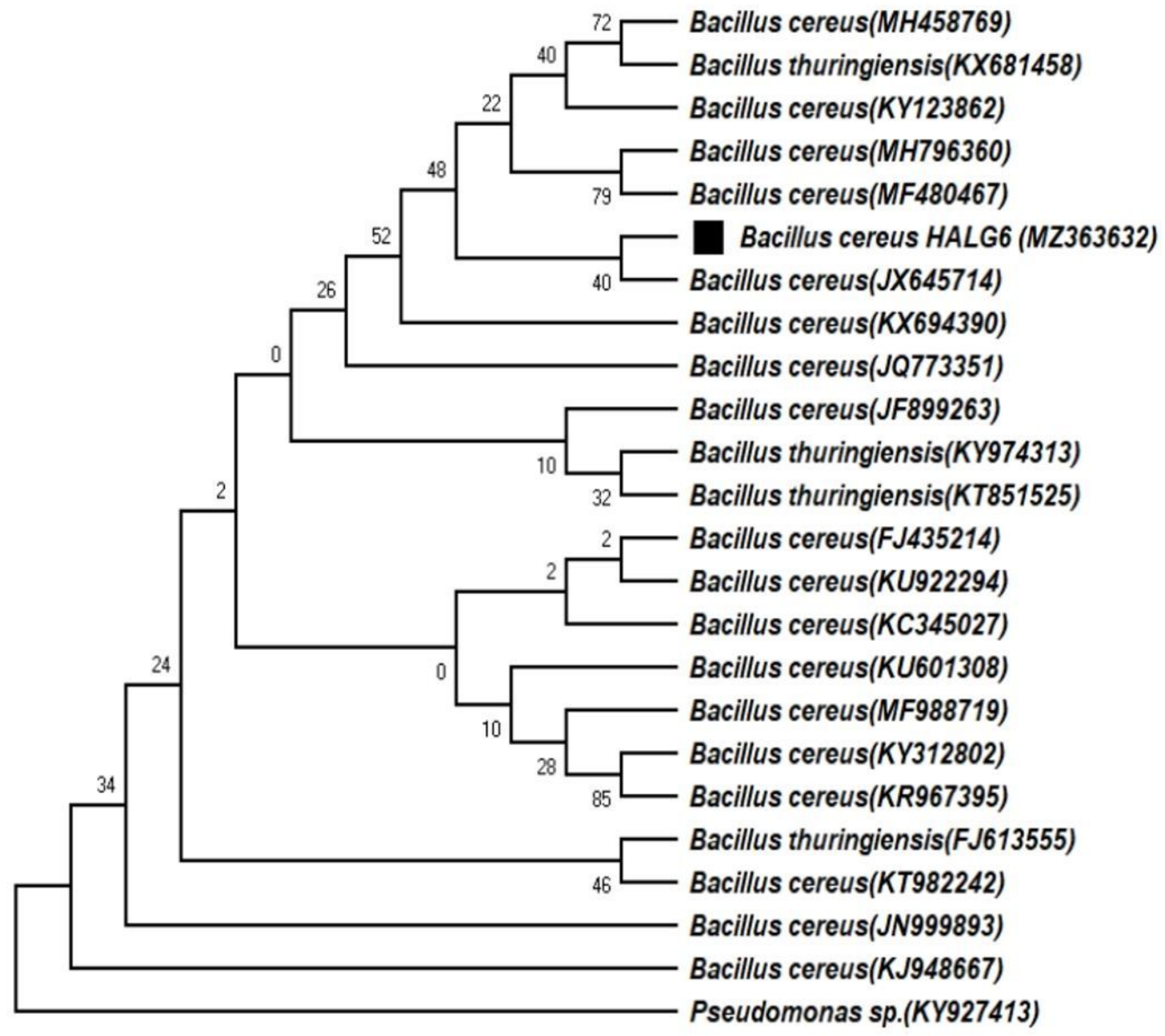

Figure 7

Phylogenetic tree constructed based on partial 16S rRNA gene sequence of HALG6 (MZ363632) strain along with the other 16S rRNA gene sequences retrieved from NCBI and RDP. 


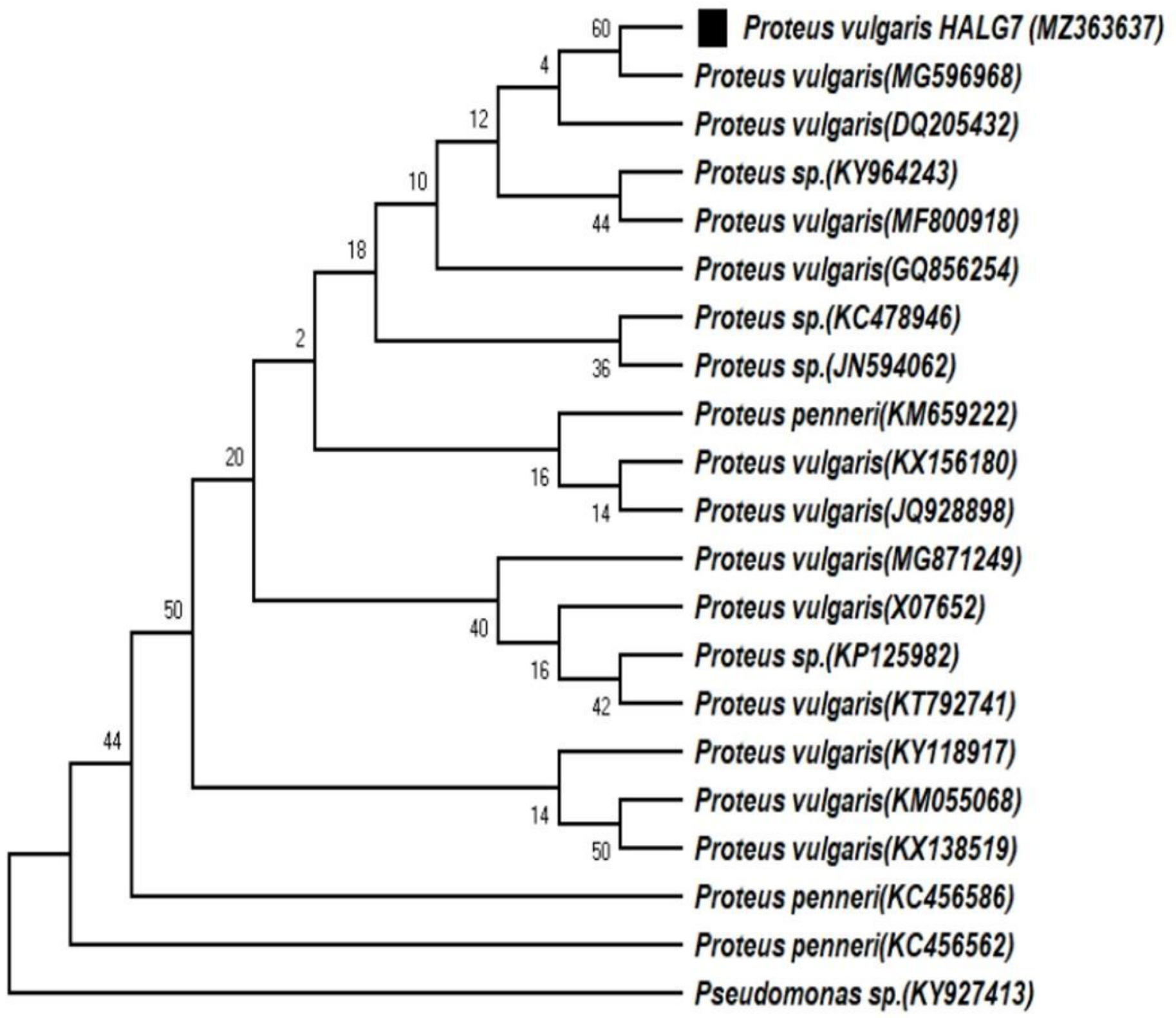

Figure 8

Phylogenetic tree constructed based on partial 16S rRNA gene sequence of HALG7 (MZ363637) strain along with the other 16S rRNA gene sequences retrieved from NCBI and RDP. 

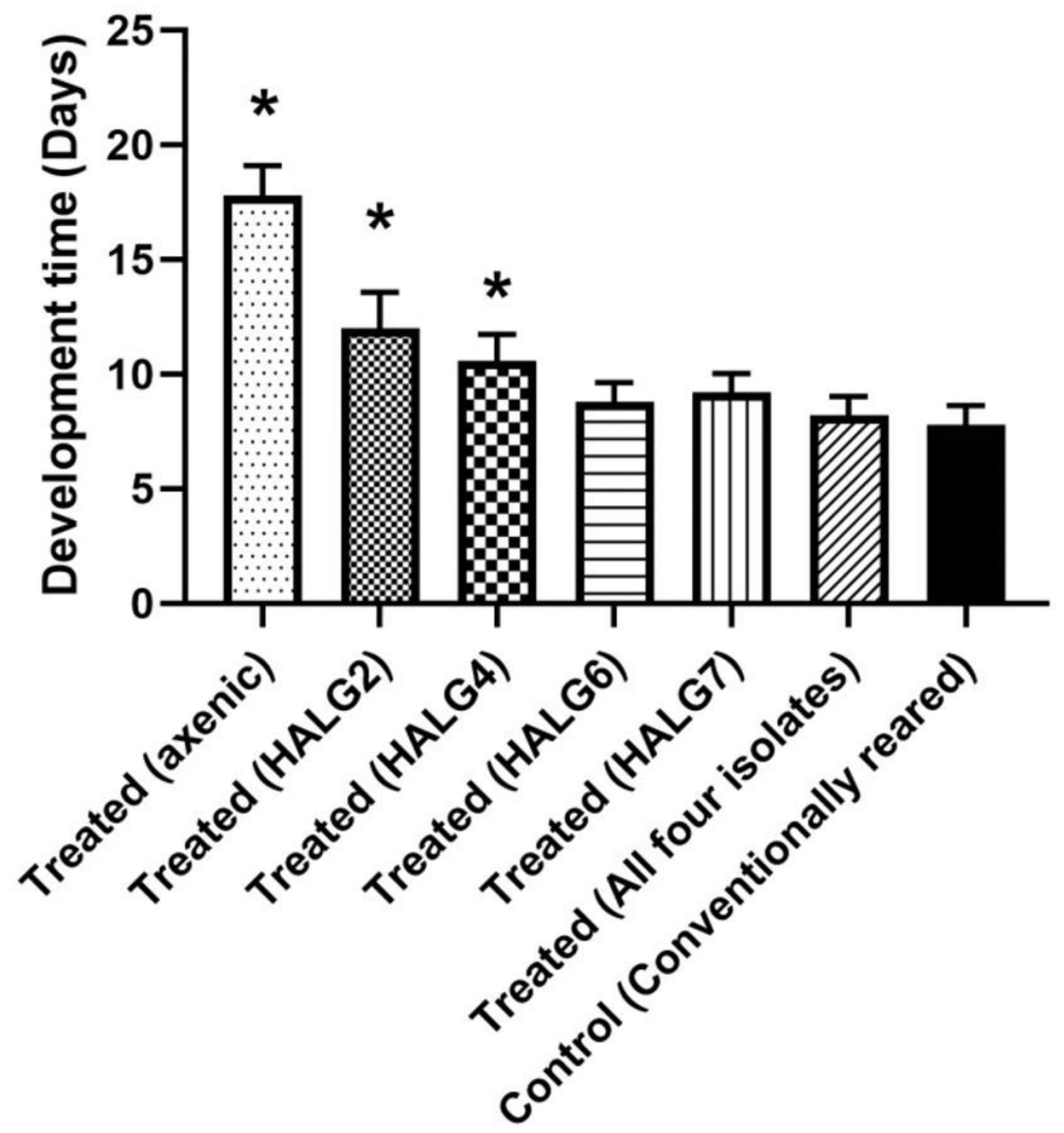

Figure 9

Time of pupation from 1 st instar larvae of Anopheles subpictus. An asterisk $\left(^{\star}\right)$ above a given bar indicates significant difference of treatment group from the conventionally reared control group as determined by Dunnett's multiple comparison test $(p<0.01)$. 


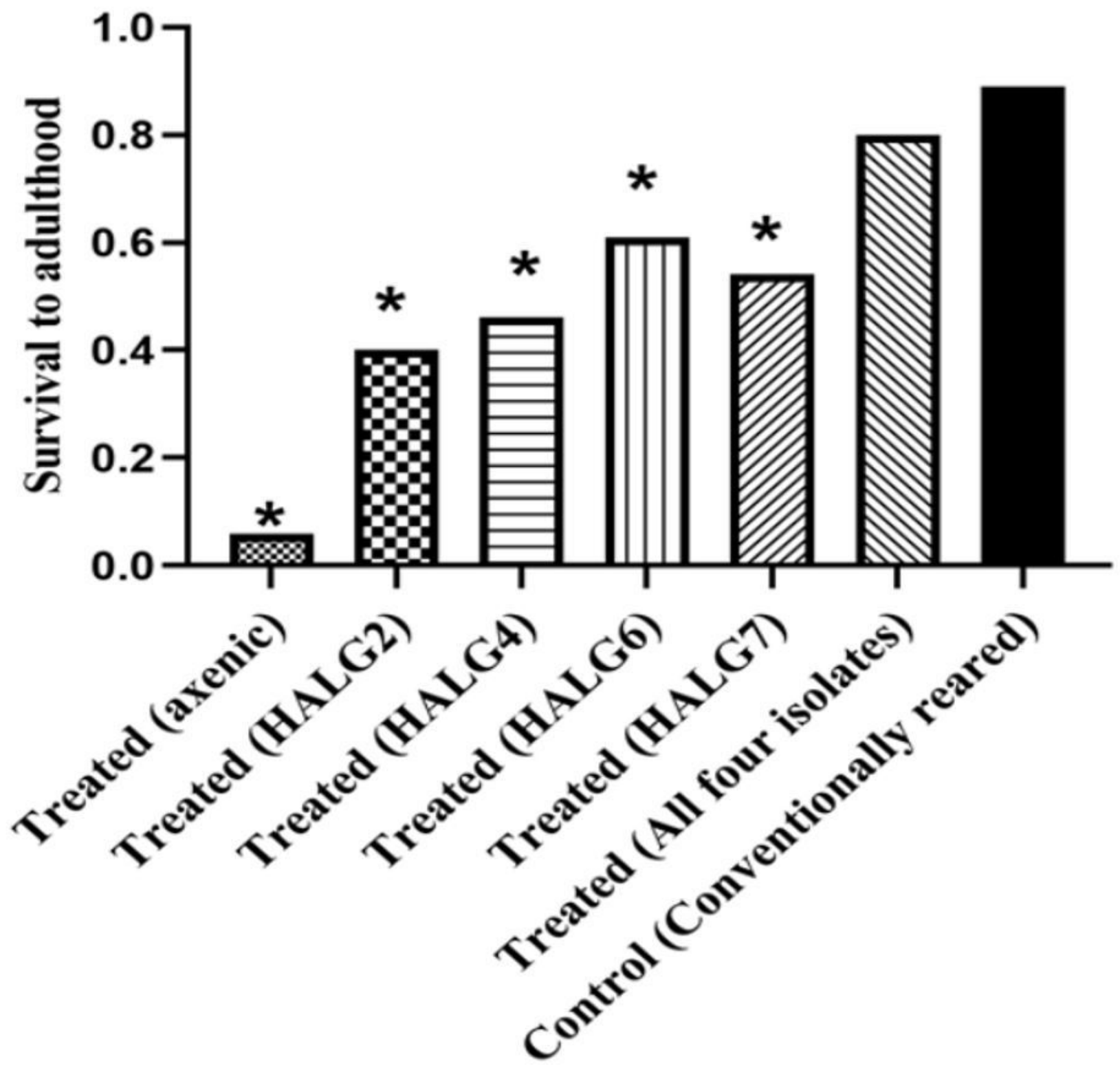

Figure 10

Rate of survival from 1 st instar larvae to adult of Anopheles subpictus. An asterisk (*) above a given bar indicates significant difference of treatment group from the conventionally reared control group as determined by Dunnett's multiple comparison test $(\mathrm{p}<0.0001)$. 
a

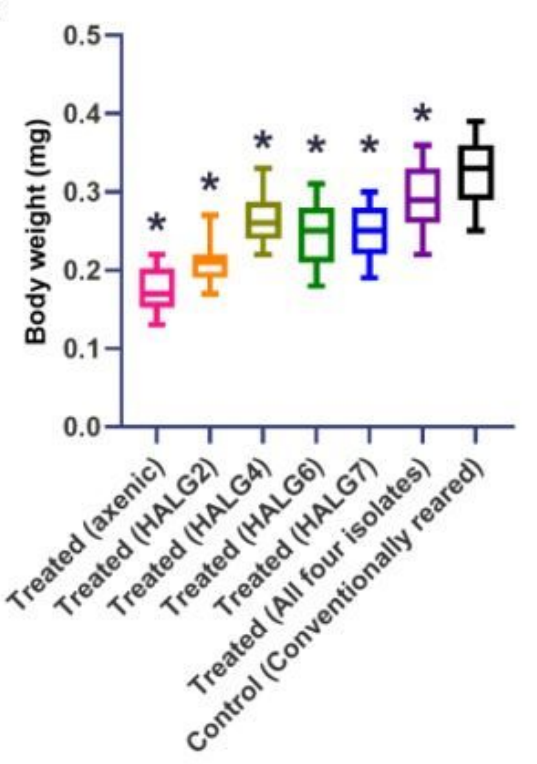

C

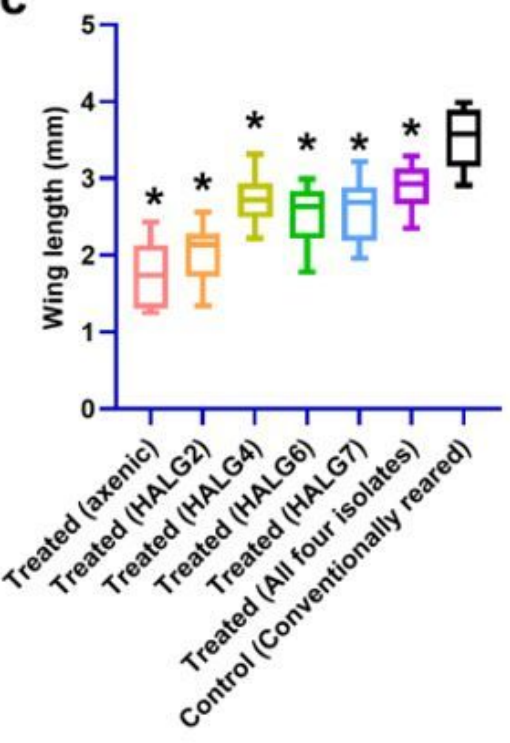

b

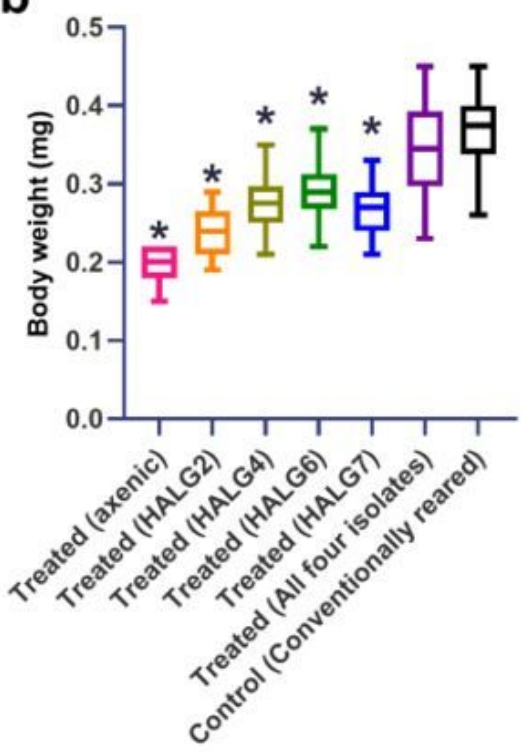

d

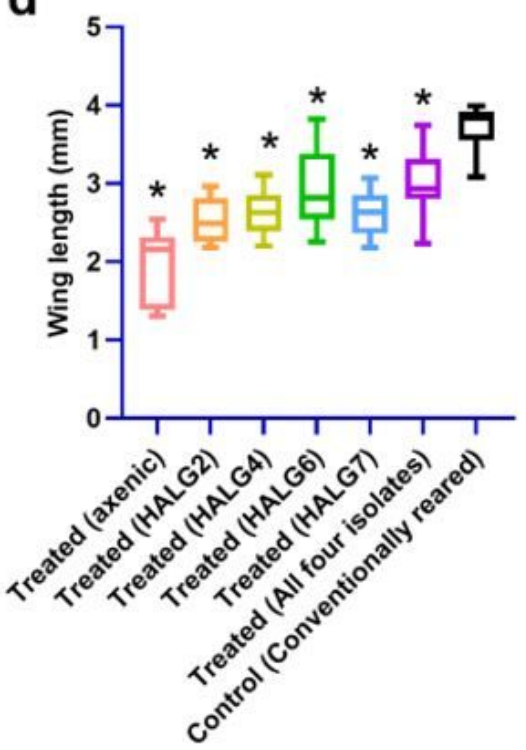

Figure 11

Body weight $(a \& b)$ and wing length ( $c \& d$ ) of adult male and female Anopheles subpictus mosquitoes. (a: body weight of male, b: body weight of female; $\mathrm{c}$ : wing length of male, d: wing length of female. An asterisk (*) above a given boxplot indicates significant difference from control group (conventionally reared) as determined by Dunnett's multiple comparison test $(p<0.01)$. 

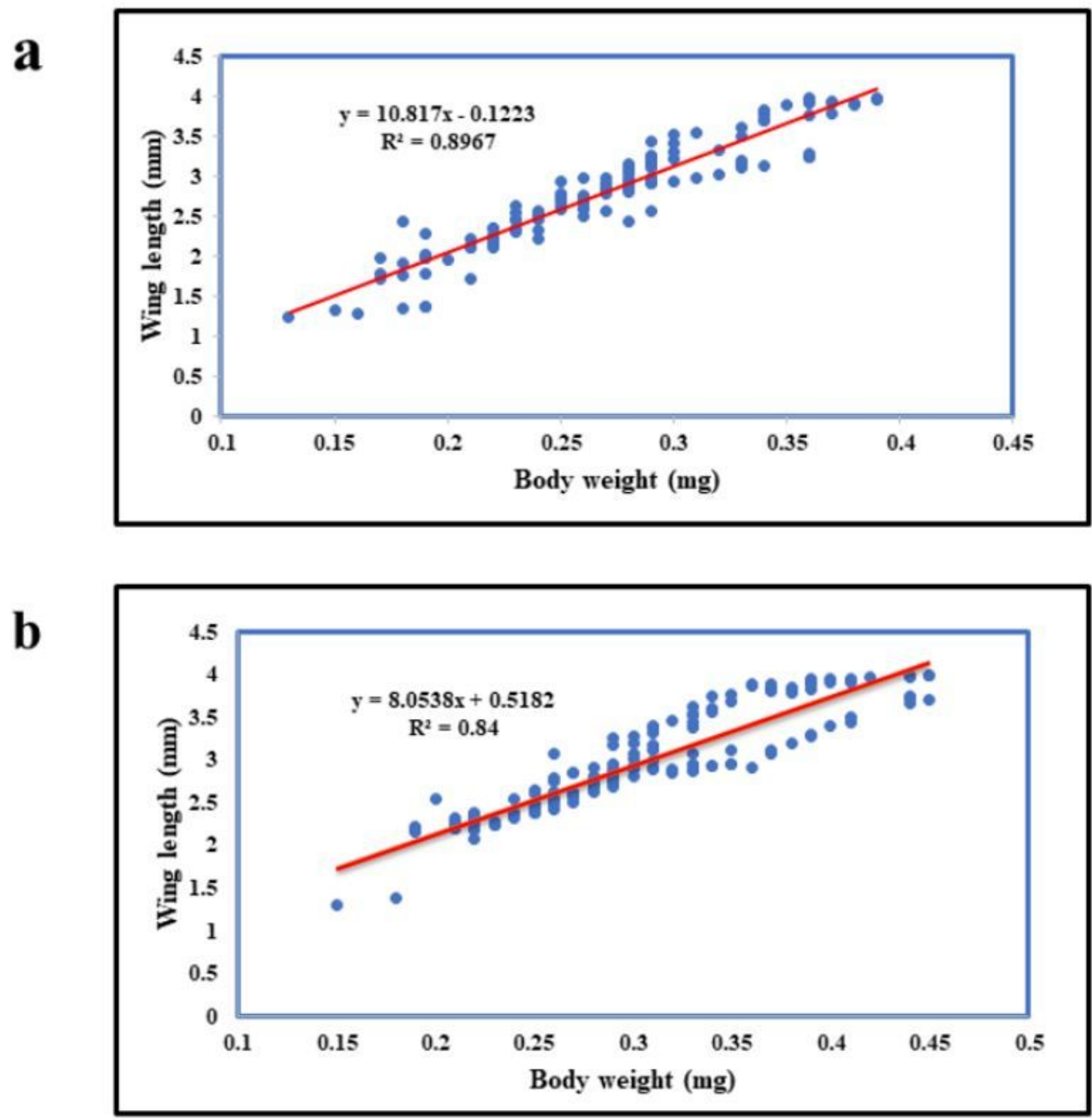

Figure 12

Correlation between body weight $(\mathrm{mg})$ and wing length $(\mathrm{mm})$ of adult Anopheles subpictus mosquitoes (a: male, b: female). 